\title{
7 RADITIONS IN TRANSITION: SOME Thoughts on late Bronze Age and eArLY Iron Age burial COSTUMES from the nORThern CaUcasus
}

\author{
Sabine Reinhold \\ Institut für Prähistorische Archäologie, Freie Universität Berlin
}

\begin{abstract}
Ornaments, jewellery, personal equipment and weapons in graves can be defined as relicts of ancient costumes and weapon assemblages which are connected to the social identities of the buried persons. At several late Bronze Age and early Iron Age sites in the north Caucasus (Koban culture) large numbers of richly furnished graves allow the reconstruction of specific costume and armour groups. These can be related to factors which structured these communities into a ranked society. This article is based on the investigation of two cemeteries in Chechenia (north-eastern Caucasus) which demonstrate the change in social differentiation during the developed Iron Age. The article also includes a general discussion about the concepts of costumes and their potential for reconstructing social identities.
\end{abstract}

Keywords: costume, early Iron Age, late Bronze Age, north Caucasian archaeology, social identities

\section{INTRODUCTION}

During recent years studies of cultural networks in the Bronze and Iron Ages of Eurasia have mostly concentrated on large-scale analyses of interregional communication systems, dynamic cultural processes, principles of exchange and social differentiation, or ritual actions (Chernykh 1992; Koryakova 1996; Kristiansen 1994, 1998).

As a basis for such analyses, the reconstruction of social identities and their patterns, social hierarchies and local interaction within the prehistoric communities under discussion is essential. Such enterprises - at least those concerning the metal ages - still focus predominantly on graves as archaeological sources and grave inventories or the appearance of burial monuments as correlates to reconstruct social structures and identities (Jørgensen 1990; Treherne 1995; Sørensen 1997). However, the extent to which this practice is methodologically sound remains unclear. In particular burial customs do not necessarily reflect what 
goes on in the world of the living and much evidence may also be incompletely preserved (Härke 1997; Schülke 1999).

This article focuses on an exploration of late Bronze/early Iron Age burial costumes in the northern Caucasus. Its location on the very demarcation line between Occident and Orient, both in the past and today, raises the question whether social structures analogous to contemporary eastern and central European cultures may be determined in these societies. The concentration on burial costumes is justified not only by the large number of extremely well furnished graves, but also because of their significance in signalling social and local identities. Especially in an area with a small-scale geographical character, which is today ethnographically very heterogeneous, a system to communicate local origin or social status by dress is likely to have existed not only among recent societies (Chenciner 1997), but also in the past.

The archaeology of this region was and still is characterized by a traditional approach, where material remains are classified into archaeological cultures, and discussion is mostly concerned with their formation, dissemination and chronology (Kozenkova 1990, 1996). Dynamic processes of cultural interaction are only discussed with reference to migration processes during the formative state of the Koban culture (Kozenkova 1990, 1996) or in consideration of nomadic intrusions of Cimmerians and Scythians during the first half of the first millennium BC (Kossack 1994; Dudarev and Berezin 1999). However, until now the debate lacks basic analyses of the social structures of these communities, and only recently have the first steps been taken to start a debate regarding differentiation in burial customs and burial equipment (Sharafutdinova 1993; Teržan 1995; Leskov and Erlich 1999).

The cemeteries of this region share a number of features, which have been recognized over the past decade as being promising evidence for the reconstruction of social organizational principles: large numbers of single inhumation burials in cemeteries used over a long period of time, the placement of graves in groups and/or rows, plentiful burial goods and, most importantly, characteristic assemblages of ornaments and armour which could be used to reconstruct burial costumes and armour sets (Jørgensen 1990; Müller 1994a, b; Sørensen 1997). Furthermore, it is possible to distinguish several cultural microregions and observe their development over approximately one millennium.

\section{BURIAL ANALYSES AND SOCIAL RECONSTRUCTION}

Funerary evidence gives the archaeologist a very direct approach towards an ancient society, as it confronts them directly with its deceased members, and also with their community's conceptions about funeral practice. However, graves are still far from being generally accepted as a source for social reconstruction. Although the major aspects of an 'archaeology of death' have been outlined in the discourse of recent decades, only some elementary concepts are shared. The basic conflict centres on the question whether or not funeral remains display the social relations of the buried individuals (Härke 1997; Schülke 1999). The critique was the 
result of the widespread theoretical discussion of burial analyses during the late 1970s. The understanding that ritual procedures during a funeral were liminal processes, parts of a rite de passage (Van Gennep 1960; Veit 1997:294-295), led from the beginning of the 1980s to an awareness of the role of the burial ritual in shaping a grave and its content. In particular Hodder (1982) and Pader (1982) drew attention to the fact that material culture, the dead body or the locality where the funeral takes place are parts of a highly ideological performance, which display a community's ideology more than social realities. In fact, the role of the dead individual as such seems to be secondary or insignificant.

However, the manner in which social realities are distorted by the funerary ritual remains an open question. Here the nature of the archaeological record under discussion is highly significant, and the strategies of analysis must take its specificity into account. The societies of the northern Caucasus examined in this article show clearly structured cemeteries. Differences in costumes and weapon assemblages are obvious and show distinctive categorization. Stray finds of similar ornaments, which are part of the burial costumes from settlements indicate that these objects were not only used in funerary contexts. The metal objects from the graves usually show clear use/wear signs, which indicate that they were indeed used as personal ornaments or weapons over a long period of time. ${ }^{1}$ Where anthropological data are available, archaeological categories like 'female/male' or 'warriors' correlate with the physical data. Obvious structures in the archaeological material supported by functional data as demanded by Härke (1993) therefore give reason to assume that the regular patterns found in the Caucasian cemeteries are indeed linked with the social identities of the ancient communities burying their dead.

\section{CORRELATES FOR SOCIAL IDENTITIES IN MORTUARY REMAINS - FACT OR FICTION?}

When dealing with the reconstruction of social identities the question arises as to which part of the archaeological record can be related to such identities. Social identity can be regarded as the acceptance of social roles, which are set by the norms of a community. They include a wide range of aspects such as local and kinship-related identities like residence, language, ethnicity or descent (Angeli 1991). Other possible identities relate to age, gender, religion or social status. During a lifetime an individual usually has various social identities, even several at the same time. However, these identities are shaped by the ideology of a community. In his article about the phenomenon of 'warrior burials' in European prehistory, Treherne (1995:115-117, citing principally Althusser and Bourdieu) called into question the sharp line which is drawn between a society's ideology and its social reality. From a sociological point of view, he argues, ideology is involved in all spheres of human existence, and furthermore, rituals - including mortuary rituals - display this ideology in an ideal form. Corporate rituals enable the individual members of a community to demonstrate their acceptance of the displayed order by using the proper iconography. In particular, mortuary rituals 
include many aspects in which specific rules must be strictly followed to reconstruct a proper social order (Van Gennep 1960; Taylor 1983; Stocchia 1992). Several authors have drawn on ethnographical parallels to criticize archaeological social interpretations based on evidence from graves (Tainter 1978; Pader 1982; Parker-Pearson 1982; Schülke 1999). Their critique points out an uncritically assumed correlation between grave-good qualities and social structures, especially linking wealth and social hierarchies. Their analogies, however, can be easily contradicted by case-studies where social differences are displayed during the funeral (for instance Stocchia 1992 for a Christian community; a more detailed list in Grainger 1998:49-51, 85-88).

My intention in this article is not to contradict these cautionary voices in general. Rather I would like to point to the need to make a careful study of the specific archaeological record in question, in order to understand how an ancient community created and expressed social identities by using specific symbols in a particular way. Objects are used by people in all societies to give their ideological orders a visual expression (Bourdieu 1976). The main problem for the archaeologist is the gap between the social identity and the symbol through which it is expressed. Symbols are part of a sign system with an explicit iconography that is only correctly understood by the people using it (Miklautz 1996:59-64). Archaeologists can never expect to reveal the explicit meaning of a particular symbol. But the repetition of characteristic patterns, for instance combinations of ornaments or weapons in a grave, gives sufficient evidence for a reconstruction of the principal categories of such a sign system. Differences in combinations can be ascertained on intra- or extra-group levels (Burström 1996:170-172).

\section{THEORIZING DRESS - THE CONCEPTS OF TRACHT}

In this article, I will focus on burial costumes as symbols for social structures in the north Caucasian late Bronze and early Iron Age. Dress offers multiple ways of expressing social order in everyday life, signifying people's interactions through a clear iconography (Gerndt 1974; Eicher and Roach-Higgins 1992; Miklautz 1996:82-92; Burmeister 1997). The study of dress is one key to understanding a society's categorization, its social values and norms. Its specific character does not only allow an individual to express conformity with the social categorization system, but also allows other members of a group to control this. Dress reconstructed from the archaeological record therefore appears to be evidence which is well suited for expressing social identities and differences. An 'archaeology of burial costumes' has to consider the characteristic use of dress and it must refer to principal phenomena of this medium, which have been discussed in studies on dress in recent societies (Bogatyrev 1971; Lindisfarne-Tapper 1997).

One of the most characteristic aspects of Tracht ${ }^{2}$ in both European and nonEuropean ethnography is its ethnic connotation (Kann 1982; Welters 1995:75-76, 65-67). Indeed in the examples cited by Kann and Welters, Tracht is primarily used to signify ethnicity. Other studies point to a stronger regional definition. Local 
origin in a region or village seems in fact to be a primary criterion for the choice of Tracht. However, restricting this generalization, Burmeister (1997:180) describes analyses by Bogatyrev (1971) from the former Yugoslavia, where only some details of the local Tracht express local origin. The degree of visibility is essential for directing the information which is communicated. Clearly visible features are aimed towards a larger audience, expressing local residence or ethnicity. Less obvious features imply more sophisticated classification, and are directed to an intra-group communication. Bogatyrev found further limitations concerning local aspects of the dress worn. He notes strong differences in the sign systems of male and female dress. Not only does the male Tracht display less regional specificity, but it is also more easily transformed. Similar differences can be detected in premodern and modern Caucasian dress (Chenciner 1997:81-83). These differences are caused by the divided inter-regional transaction spheres of the two genders, and the different social roles of men and women in society in general. ${ }^{3}$ Obviously female Tracht reflects predominantly local identities, while male costume expresses larger entities and in addition can also display political identities. The polarity of the male/female identities becomes especially evident under social pressure (Lindisfarne-Tapper 1997:71-72).

The second general aspect of Tracht is the manifestation of the horizontal and vertical structures of a community (Bogatyrev 1971:46-72; Lindisfarne-Tapper 1997:72-78). Gender-specific dress and gear is the most frequent and obvious difference between the two sexes. Their variance is established by the different identities of men and women (Sofaer Derevenski 1997:486-488). As important as gender is the classification of age, status or state of life, for example warrior status, married or unmarried (Bogatyrev 1971:64-72; Stocchia 1992:40, 44; Eicher and Erekosima 1995:147; Lindisfarne-Tapper 1997:72-78). Less important, but also sometimes displayed is the membership of specific circles like warrior and ritual societies. As in the first aspect, women again seem to be more the object of visual categorization than men; for instance, women's marital status is frequently reported as a basic criterion for their choice of costumes (Bogatyrev 1971; Stocchia 1992; Eicher and Erekosima 1995; Lindisfarne-Tapper 1997). This is linked to the fact that marital status is an important medium for creating social relationships via kinship relations. Interestingly, material wealth takes a secondary role to these principal elements of social ranking, as Bogatyrev (1971:49-52) observed in a survey of Slovakian male and female dresses. Although wealth can affect the quality and number of some details like special textiles or jewellery, the difference, for instance, between the Tracht of a married woman and that of an unmarried woman is much sharper than that between a poor and a wealthy person of the same group. Only under particular circumstances can the display of wealth through dress become an important factor of social communication. In societies where material wealth is a basic criterion for social status, the quality and quantity of the Tracht components become important. The demonstration of increasingly valuable accessories becomes a means of social categorization, where Tracht is now subject to changing fashions. 


\section{TRACHT IN CHANGE}

This portrait of Tracht has drawn a rather static view of the aspects that are symbolized by dress codes. However, one should not deny the chronological factor both of the social identities that are expressed and the means of expression itself. Tracht is a part and a product of historical and contextual processes, it shares with them the flux of time. Specific modes of dress appear and disappear, according to a society's need for self-expression and differentiation (Burmeister 1997:184-187). Incorporation of new groups may transform the social circumstances (Yamani 1997:56-59), economic change may result in a desire to express wealth (Bulst 1993; Jaritz 1993; Yamani 1997:59-63), political change can lead to a complete change of dress, either by choice or by force (Baker 1997; Lindisfarne-Tapper 1997:71-72; Norton 1997). It is essential that with the change of Tracht, we have to consider a shift in its traditional elements (Gerndt 1974) or as Bogatyrev (1971: 93) states:

A change in costume is only a part of an over-all change in the structure of life based on such things as people's world view, economic system etc. It will be impossible to maintain artificially one part of the structure when the latter undergoes a complete change.

Whether slight transformations or radical change, it is highly probable that dress codes will mirror this. In doing so, Tracht also embodies an important medium for the creation of new identities, sometimes in direct opposition to traditional structures. For instance, changing one's Tracht in order to oppose a system of socially accepted symbols is a risky venture, and a threat to all social values. In a changing society, however, individuals - or perhaps even groups - with higher social prestige and substantial means of power, which are less vulnerable to social reprimand, can use new dress codes to demonstrate their ability to overcome old structures (Burmeister 1997:187).

\section{Burial costumes as Tracht}

The reconstruction of ancient dress from archaeological remains has to consider that burial costumes represent a very specific ritual expression of a community's attitude towards the presentation of its dead members - the deceased do not dress themselves. Studies of the aspects symbolized by Tracht, however, agree that there is no difference in structural principles between a festive costume and everyday dress (Bogatyrev 1971). It might only be more formal. Moreover, studies of 'death costumes' from an ethnographic or historical context have shown that very often a festive costume is also used as a burial costume ${ }^{4}$ (Stocchia 1992). An analogous structure of these different costume classes is therefore a reasonable hypothesis. The crucial point here is whether a deceased member is buried in the costume that relates to their status at the point of death. When the modification of status after death is incorporated in the burial concept, for instance advancing the deceased in age, or a change of social role, the possibility of marriage or advancing them in the 
family hierarchy, we should expect a very similar grave assemblage for all individuals and very few distinctions in burial costumes. An 'advanced' age is sometimes recognizable in burials of children, where small children are equipped with adult items. ${ }^{5}$

The further discussion of this article will be dedicated to a special case study, the reconstruction of late Bronze Age/early Iron Age costumes and weapon assemblages of burials from the northern Caucasus. There we may indeed be able to trace some of the characteristic features described earlier in this article in the archaeological record. The north Caucasian example is an ideal case to investigate burial costumes from a socio-cultural perspective. The archaeological material is visibly categorized, the long use of some sites and the existence of several neighbouring micro-regions allow both a diachronic and a synchronic perspective.

\section{The late Bronze Age/early Iron Age Koban culture - the ARCHAEOLOGICAL SETTING}

The archaeological culture of the late Bronze Age/early Iron Age in the northern Caucasus is traditionally known as the Koban culture (Fig. 1). It comprises several archaeological groups ${ }^{6}$ on the northern slope of the Caucasus (Kozenkova 1996:62-73, Figs 26-29; Reinhold 2002). As Fig. 2 shows, the Koban culture existed during the second half of the second millennium and the first half of the first millennium BC (Kozenkova 1990). It is divided into a first, pre-Scythian period, late Bronze Age/early Iron Age, and a second phase, late Iron Age, during which

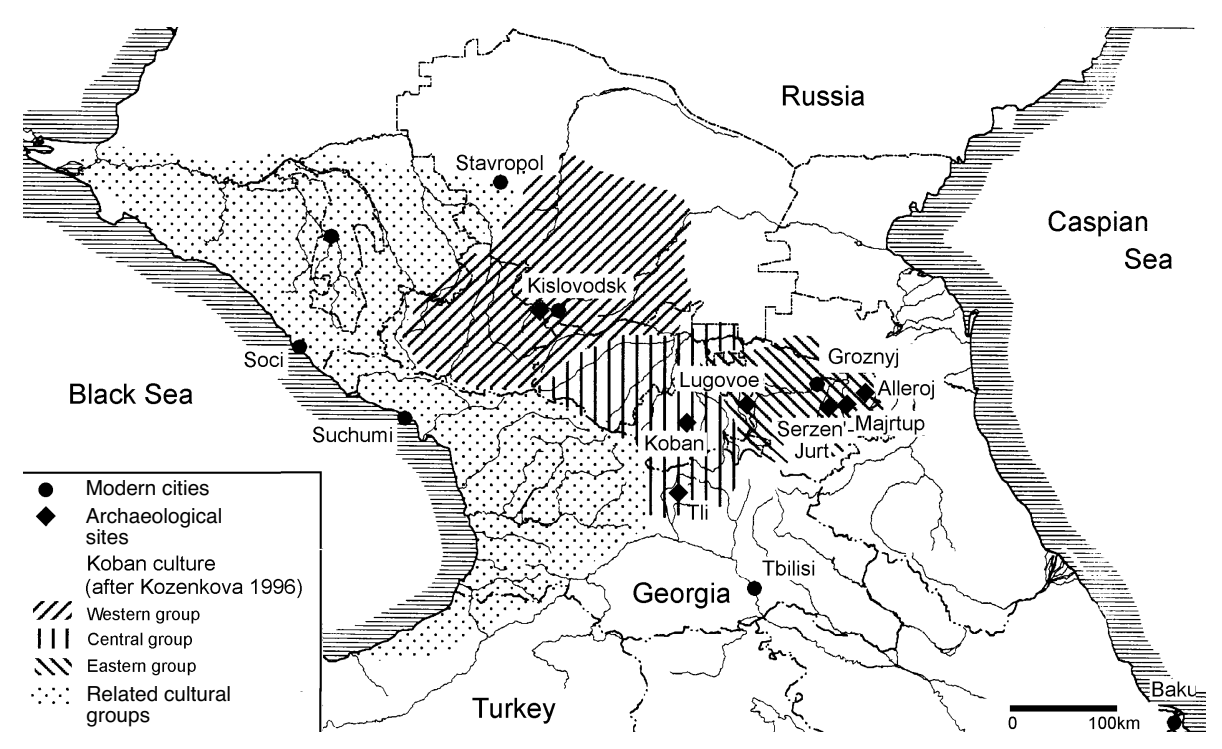

Figure 1. Map of the northern Caucasus with the regional groups of Koban Culture - after Kozenkova 1996: Fig. 26. 


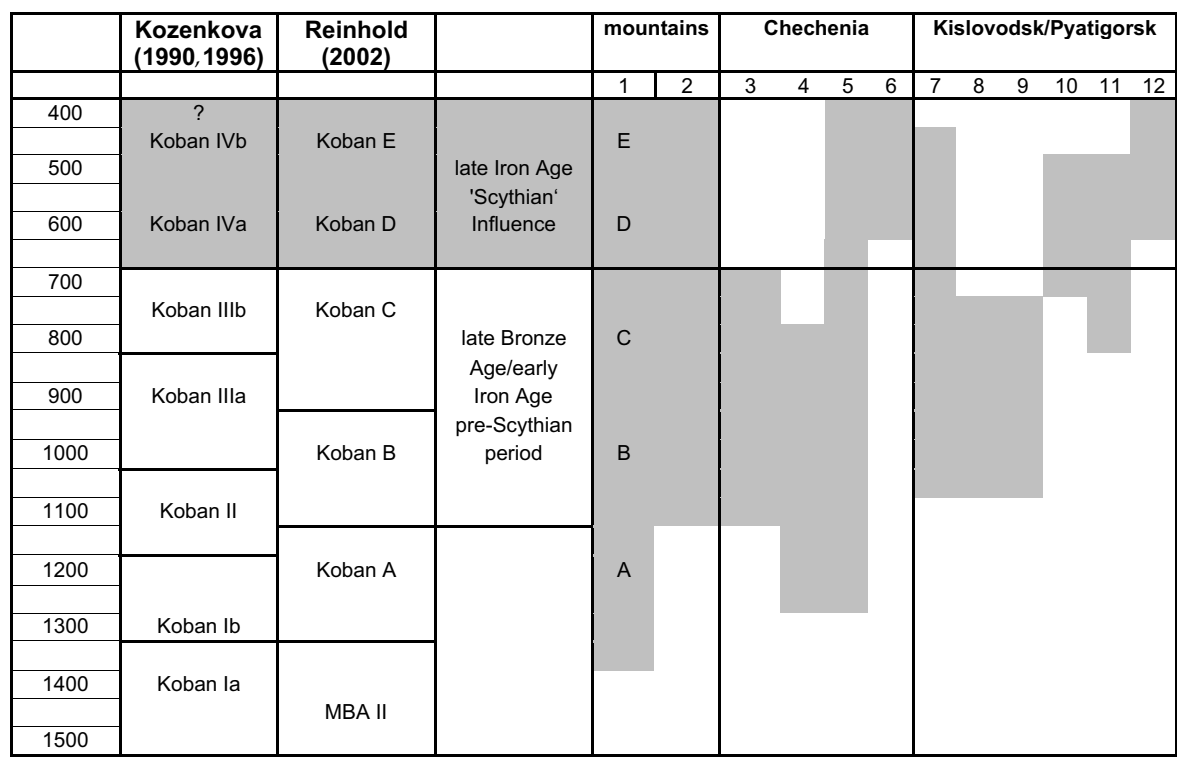

Figure 2. Chronology and approximate use of cemeteries.

$1=$ Tli; $2=$ Koban; $3=$ Serzen' $-J u r t ; 4=$ Majrtup 2; $5=$ Alleroj $1 ; 6=$ Lugovoe; $7=$ Klin Jar; 8 $=$ Mebel'naya fabrika; $9=$ Berezovka $1-5 ; 10=$ Ullubaganaly; $11=$ Mineralyye Vody; $12=$ Karras 1.

substantial Scythian influence is obvious in both the material culture and burial practices (Kozenkova 1996:99-106).

In the Bronze Age and Iron Age, archaeological groups are located along the slopes of the mountains and in the foothills between the mountains and the steppe. The area is divided into several micro-regions with different ecological settings. This division into small geographical areas is also reflected in the archaeological material, where local differences can be seen. The archaeological record indicates wealthy communities in a densely settled landscape (Korobov 2001, Figs 3-4). However, excavations of settlements indicate that villages seldom exceeded 1-2 ha. Where settlements have been excavated, regular rows of small houses without a hierarchical structure have been found (Kozenkova 1977:11-18, Table III; 1989:62-69). No settlement hierarchy can be identified. Beside the settlements a large number of cemeteries with flat inhumation graves have been excavated. There can be as many as 1000 burials per cemetery, which reflect strong local settlement and ritual traditions. The majority of the graves included a large number of burial gifts. Among the grave-goods, objects of personal use and adornment, remains of burial costumes and armour are prevalent.

During the late Bronze Age, the burial customs changed from collective to individual burials. But even before this transformation, it was common for single persons to be buried in individual burial costumes, and with individual weapons (Reinhold 2002:421-422, 443). After the custom of single inhumation burial was 
established, it becomes possible to determine distinctive types of burial costumes and armour in each of the cemeteries and micro-regions (Sharafutdinova 1993; Teržan 1995; Reinhold 1996, 1997; Leskov and Erlich 1999).

A site which is characteristic of the central group of the Koban culture in the high mountains is the cemetery of Tli, which was excavated during the late 1970s (Techov 1980, 1981, 1985). Here more than 450 graves were excavated. Another famous site is Koban itself with an estimated number of more than 3000 burials, which were plundered during the late nineteenth century. In both cemeteries ornaments are present both in female and male burials. ${ }^{7}$ Male costumes were combinations of fibula and belts, while female costumes included necklaces, bracelets and foot-rings. At the sites of the western and eastern groups of the Koban culture, as at the sites around Kislovodsk (Dudarev and Berezin 1999; Härke and Belinskij 2000) or Serzen'-Jurt in Chechenia (Kozenkova 1992), male and female ${ }^{8}$ grave-goods seemed likewise to be distinguished by gender specific criteria: armour and few ornaments for males, no arms and rich adornment for females. Typological differences for the two genders can also be noted. The only shared component there are vessels that contained food.

\section{Female costumes - geographical AND CHRONOlOgicAl PERSPECTIVES}

The most impressive female costumes from the northern Caucasus were found at sites in central Chechenia, Serzen'-Jurt and Majrtup (Kozenkova 1992; Vinogradov and Dudarev 2000). Both sites existed during the pre-Scythian phase of the late Bronze/early Iron Age. Serzen'-Jurt is the largest excavated site in this area. The majority of the cemetery has been excavated and included a little more than 100 graves. This is the only site in the northern Caucasus where the neighbouring settlement has also been excavated. In the graves of Serzen'-Jurt we find an extraordinary set of assemblages, including artificial plaits made of strips of bronze sheet, sets of temple-rings, pins, bracelets and belt ornaments which present a very striking appearance (Fig. 3). However, considering the entire series of female graves at this most important site, distinctive differences in the number and details of these costumes soon become apparent (Reinhold 1996, 1997). One of these details is the presence or absence of the main visual attribute, artificial plaits. Another is the number of bracelets. Three major kinds of costume (Figs 4 and 5) can be distinguished based on these differences: one costume with plaits, templerings and bracelets, one without the plaits but with temple-rings and bracelets and one with either temple-rings or bracelets. Within each group there seems to be a further distinction based on the number of bracelets and temple-rings. More individual components seem to be pins, headgear, necklaces and belts, which are found in combination with the first two costume groups. The female burial costumes of Serzen'-Jurt consequently involve three levels: one categorical level in which presence or absence of artificial plaits represents a highly visible expression of female status, a middle-range level where the number of bracelets indicates a less visible ranking and an individual component where ornaments can be added to express less definite identities (Reinhold 1996). The types used at these different 


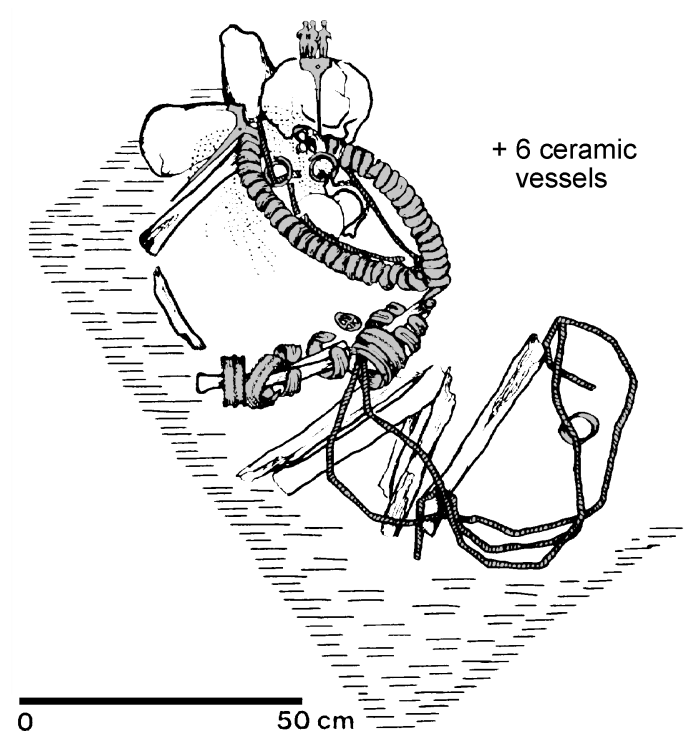

Figure 3. Serzen'-Jurt, grave 41 (after Kozenkova 1992). of different levels of classification which correspond with different levels of visibility is a convincing argument to understand the Serzen'-Jurt burial costumes as Tracht. It is significant that these costumes do not change in structure or in detail throughout almost the entire period of approximately 300 years that the cemetery was in use (Kozenkova 1992:49, 66-72). Likewise, there are no outstanding plots recognizable in the site plan; all classes of costumes are distributed equally throughout the area (Fig. 6.1). ${ }^{9}$

The existence of such a visibly classified community leads to two questions. First, is the static classification of the female burial costumes at Serzen'-Jurt a unique phenomenon? Or, second, can we find similar costumes at further sites in the Chechenian micro-region? A site with an almost identical classification of costumes and material culture is Majrtup 2, which is situated approximately $15 \mathrm{~km}$ east of Serzen'-Jurt (Vinogradov and Dudarev 2000). Further sites like Alleroj 1, Achkincu Barzoij or Shali, where artificial plaits and similar bracelets were found (see Fig. 7) are scattered around Serzen'-Jurt at similar distances (Reinhold 2002:384-386). However, at the site of Alleroj 1, only $35 \mathrm{~km}$ further east of Serzen'Jurt but in a different valley, the burial costumes included only the artificial plaits or the specific bracelets without the rest of the assemblage (Kozenkova 1977:Tab. XII, 2). Considering this, we can reconstruct an area of approximately $20-30 \mathrm{~km}$ in diameter where the typical features of the 'Serzen'-Jurt costume' were known and used to signify female identities. All sites indicate a strict categorization, although only at Majrtup 2 is the number of graves excavated sufficient to compare it to Serzen'-Jurt.

The 'Serzen'-Jurt costume' can be seen as a prototype representative for other 


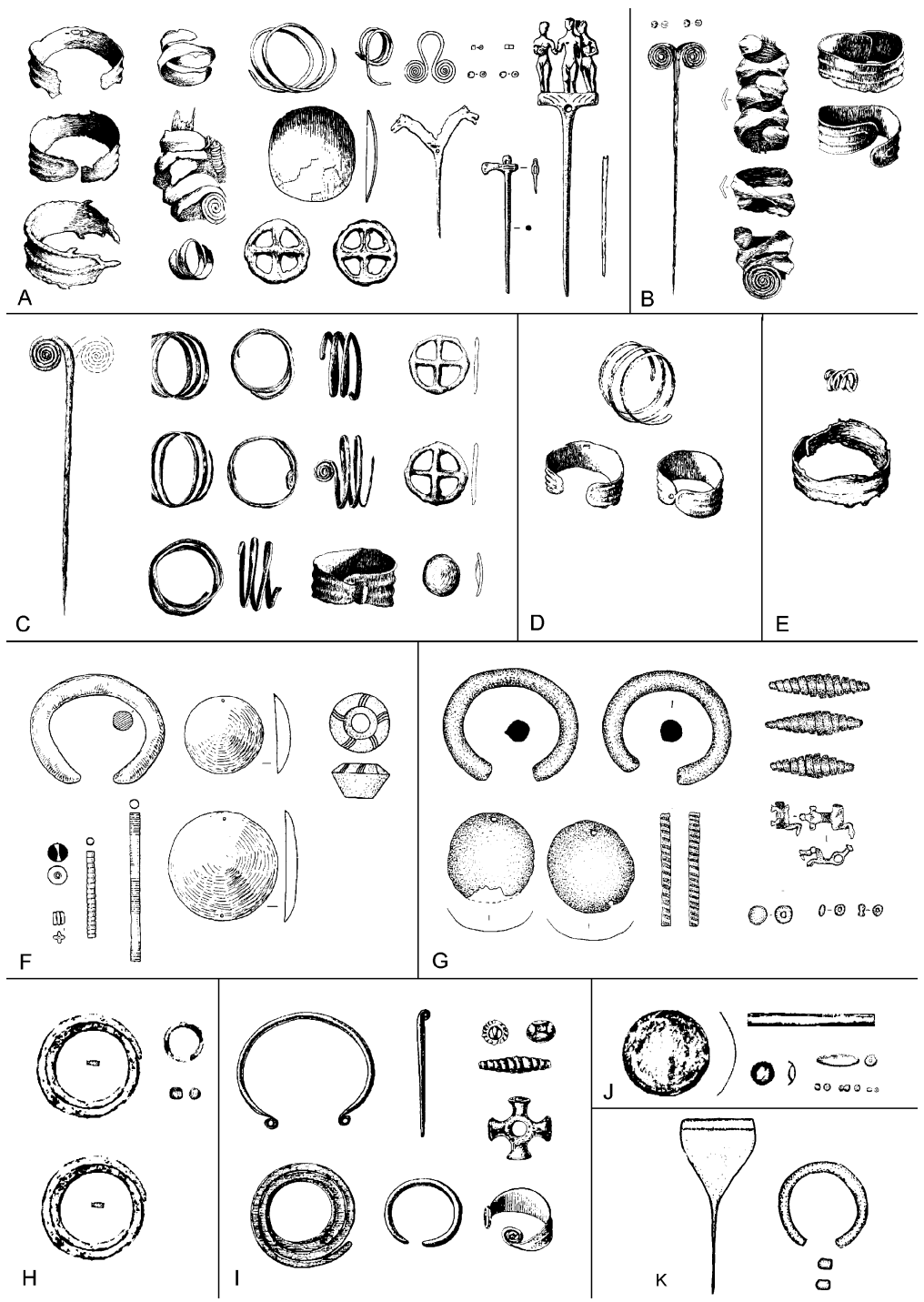

Figure 4. Late Bronze Age/early Iron Age female graves from Serzen'-Jurt (A-E, after Kozenkova 1992) and Kislovodsk (F-I, after Kozenkova 1982, Dudarev 1999 and Reinhold 2002). Ceramic material omitted.

$\mathrm{A}=$ Serzen'-Jurt, grave $41 ; \mathrm{B}=$ grave $84 ; \mathrm{C}=$ grave $88 ; \mathrm{D}=$ grave $4 ; \mathrm{E}=$ grave $60 ; \mathrm{F}=$ KislovodskIndustrija, grave 9; $\mathrm{G}=$ Kislovodsk-Lermontovskaja skala 3, grave 3/1989; $\mathrm{H}=$ KislovodskEckivas, grave 2; I = Kislovodsk-Mebelnaja-fabrika, grave 25; J = Kislovodsk-Industrija, grave 5, grave 9; $K=$ Kislovodsk-Suchaja balka, grave 2 . Scale: $A-E, H-K \approx 1: 7, F-G \approx 1: 4$.

costume areas (Trachtkreise) during the pre-Scythian late Bronze/early Iron Age in the northern Caucasus (Reinhold 2002:382-408. See also Fig. 7 of this article). A further costume area is found in the central mountain range, at sites like Tli and Koban. Here leg-rings in combination with bracelets are the dominant detail, 

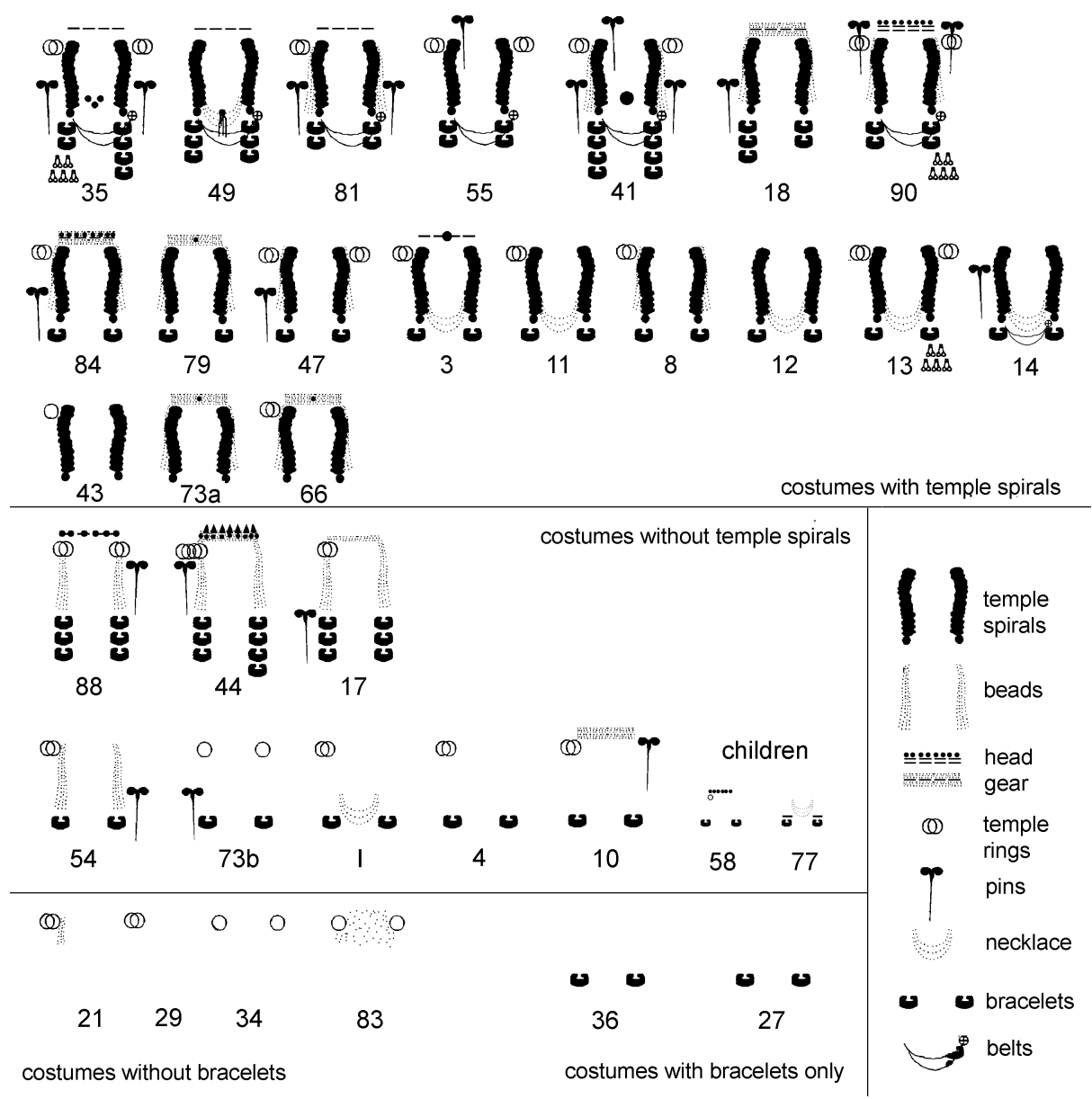

Figure 5. Serzen'-Jurt - burial costumes of graves without weapons.

although female costumes include a large quantity of individual objects. Another costume area is located in the area of Kislovodsk/Pyatigorsk. There a specific combination of buckles formed a characteristic head-dress, combined either with neck-rings and pins or with bracelets (Dudarev and Berezin 1999; Härke and Belinskij 2000:196-197). The three-levelled classification structure, like at Serzen'Jurt, can only be found in the Kislovodsk basin. The various sites differ more in the objects that form the costumes than further east, and smaller areas of similar costumes can be noted (Reinhold 2002:392-394). A somewhat poorer costume type where only one pin per grave appears in the archaeological record, is located in the tributaries of the lower Kuban and a last group, again with leg-rings, is situated in Abkhazia. Although occasionally less striking in appearance, these costume areas share the multilevelled character of the 'Serzen'-Jurt-costumes', as well as its conservatism in structure and typology. 


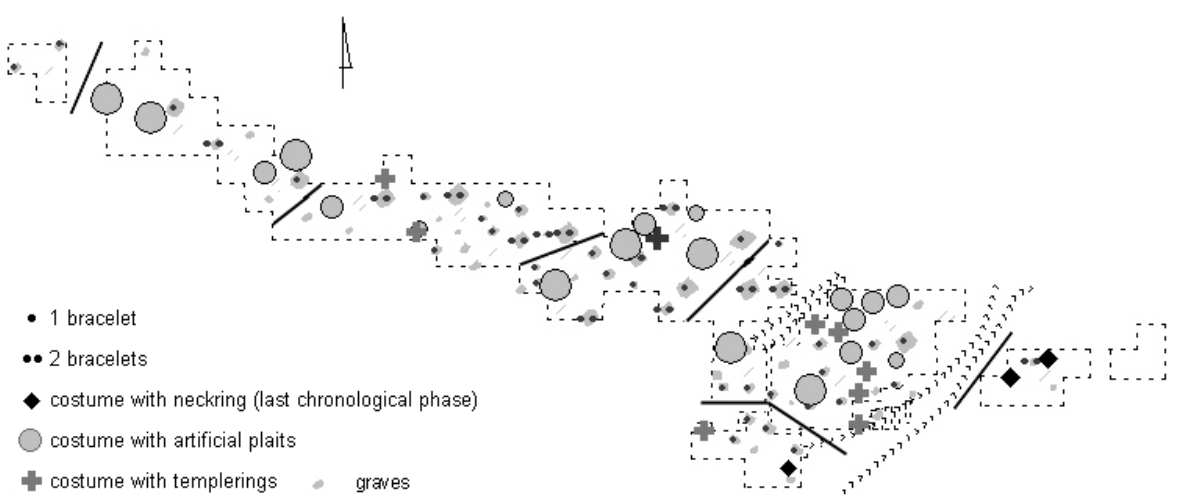

Figure 6.1. Serzen'-Jurt-distribution of burial costumes.

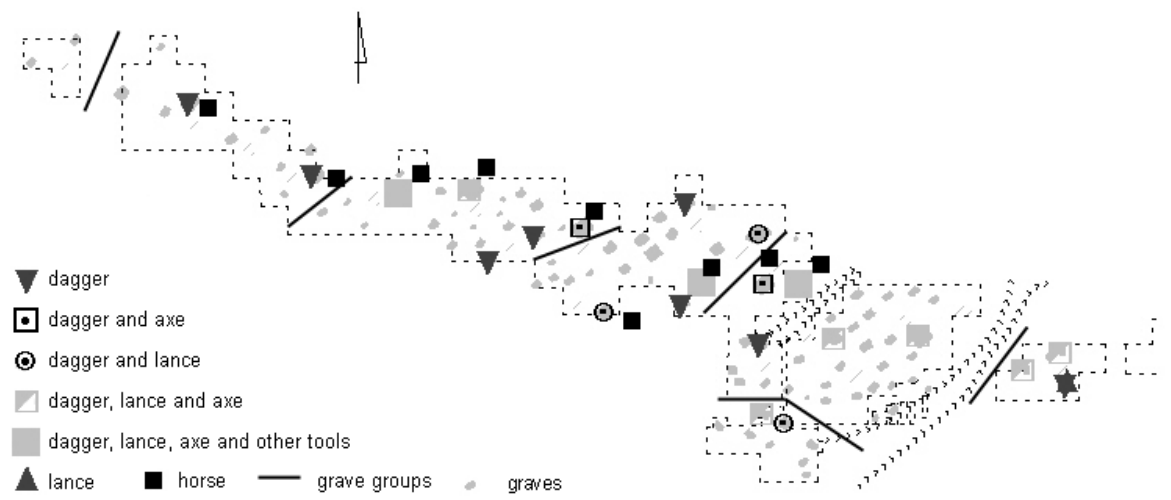

Figure 6. 2. Serzen'-Jurt-distribution of armament.

During the later Iron Age, the former homogeneity changes. In some areas there is a significant Scythian influence in the material culture (Kozenkova 1996:99-103, Fig. 37). At many sites the cemetery is abandoned, shifted to a nearby location or new burial grounds are established. At the same time there is also a distinctive change visible in the burial costumes. At Serzen'-Jurt, for instance, the last burials dating to the initial stage of this period display a completely altered costume with neck-ring and small bracelets (Kozenkova 1992:Table 21). The structure of the costumes also changes.

In the newly established cemetery of Lugovoe, also situated in Chechenia, this process of transformation occurs during the site's use. Two-thirds of this cemetery was excavated in the late 1950s, revealing 165 graves (Munchaev 1963). The local chronology covers roughly 300 years from the mid-eighth to the mid-fifth century BC and can be divided into three chronological phases (Reinhold 1997:170-171, Figs 11-12). Costumes are present as in the former pre-Scythian period, but 


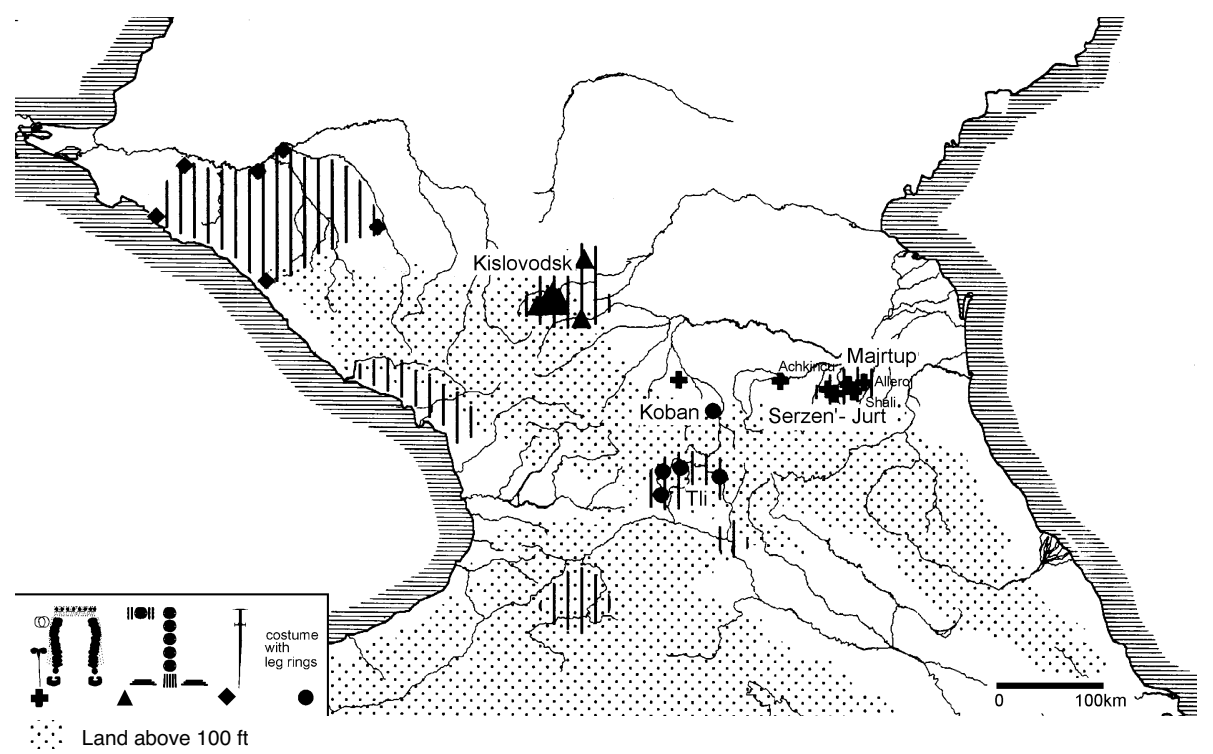

Figure 7. Costume areas of the pre-Scythian period in the Caucasus. Areas shaded with vertical lines mark the area of the costumes' use, symbols (see key) mark graveyards with costumes in situ. $\mathbf{+}=$ costume with temple spirals, Seržen'-Jurt type, $\mathbf{\Delta}=$ costume with head and plait gear, Kislovodsk type, - costume with pins only, Kuban type, $\boldsymbol{\bullet}=$ costumes with leg rings, Koban type.

patterns are far less visible (Fig. 8). Although some basic combinations of braid fasteners, belts and neck-rings, sometimes combined with bracelets or single neckrings, are present, the combinations seem much more variable than before. The variability increases over time. A group of exceptionally rich dresses appears in the

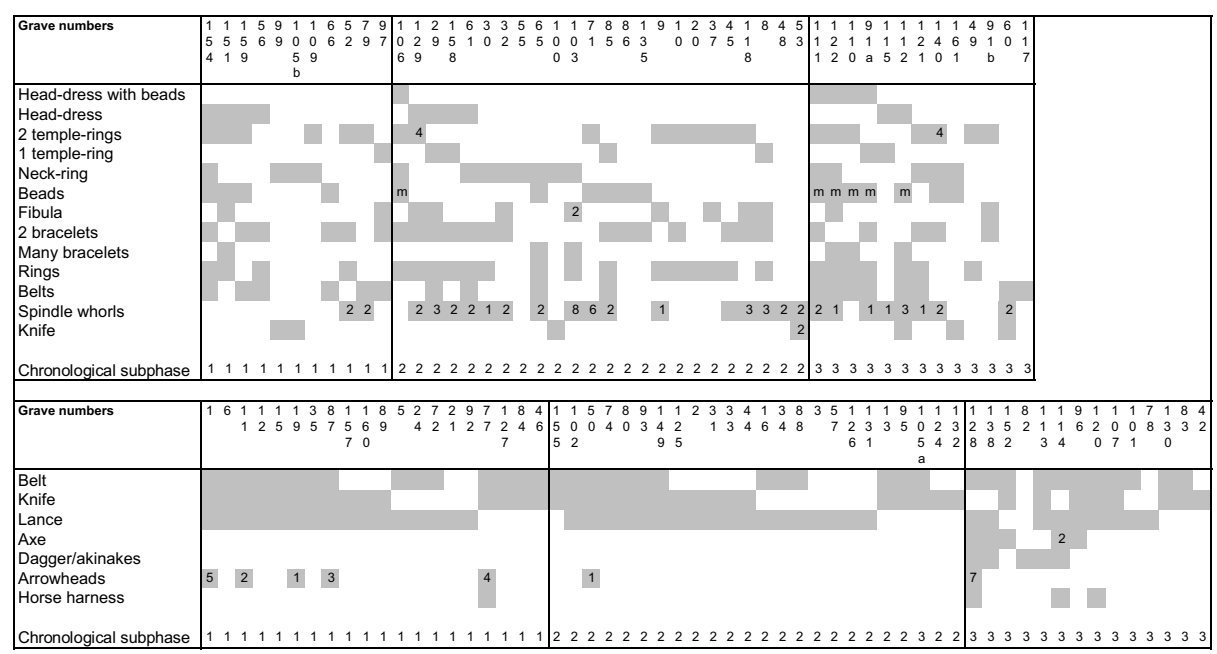

Figure 8. Lugovoe - principal costume elements and weapon combinations. 


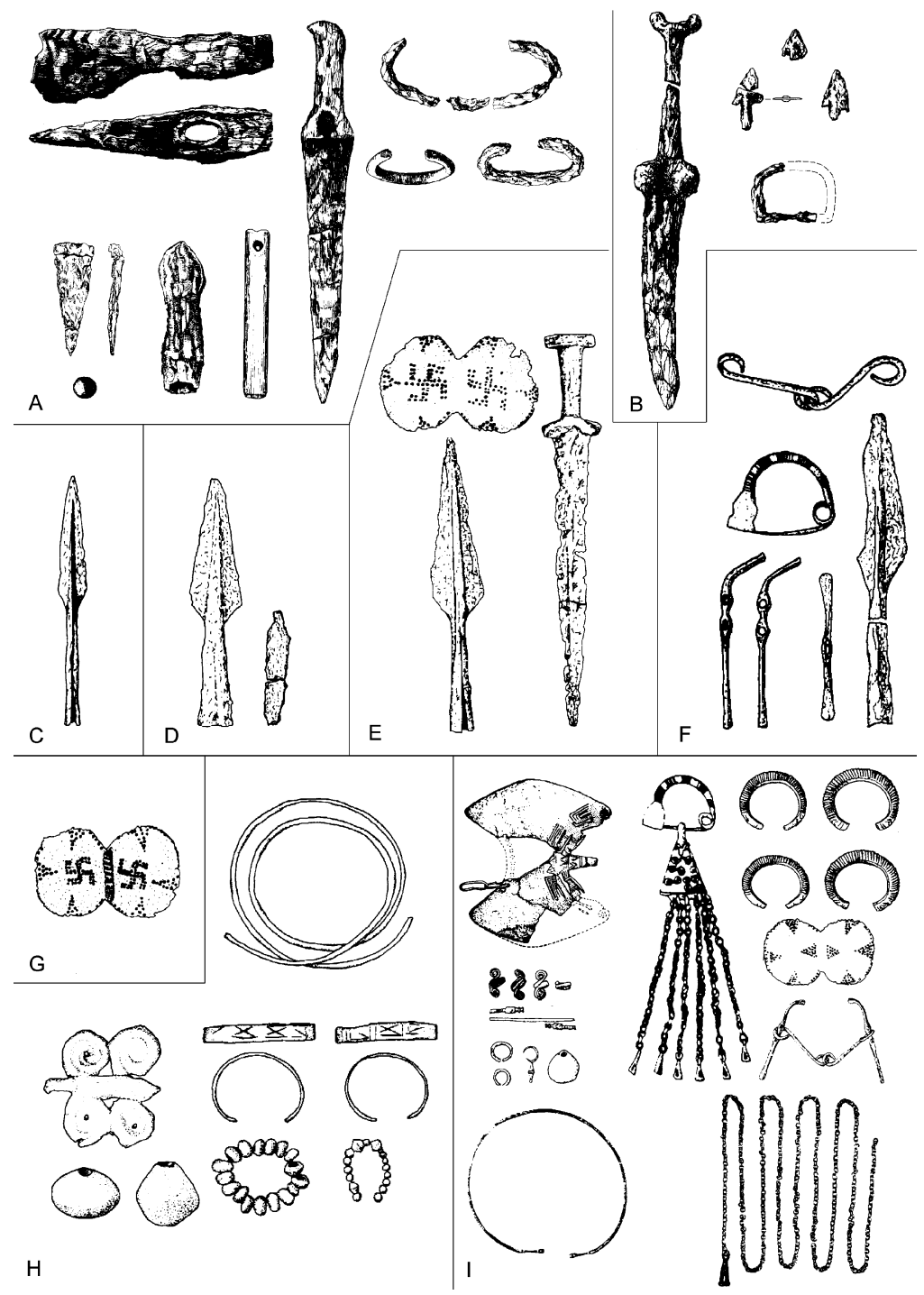

Figure 9. Late Iron Age graves from Serzen'-Jurt (A-B, after Kozenkova 1992) and Lugovoe (C-I, after Munchaev 1963). Ceramic material omitted.

$\mathrm{A}=$ Serzen'-Jurt, grave II3; $\mathrm{B}=$ grave II4b; $\mathrm{C}=$ Lugovoe, grave 90; $\mathrm{D}=$ grave 93; $\mathrm{E}$ = grave $101 ; \mathrm{F}=$ grave $114 ; \mathrm{G}=$ grave $105 \mathrm{a} ; \mathrm{H}=$ grave $65 ; \mathrm{I}=$ grave 122 . Scale: $\mathrm{A}-\mathrm{B} \approx 1: 7, \mathrm{C}-\mathrm{I} \approx 1: 5$.

second and third phase. They include broad ribbons embroidered with several hundreds of beads, remains of caps, temple-rings and massive decorated bronze belt-plates (Fig. 9, I). But unlike at Serzen'-Jurt, it is impossible to distinguish combinations of distinctive elements. These dresses are arranged very individually, but they use the same types of items as the less plentiful combinations (Fig. 9, G 
and $\mathrm{H}$ ) and include the features which were obviously important for female costumes in Lugovoe: braid fasteners, belts and neck-rings. Thus, the exceptional dresses include the local female costume, i.e. the socially accepted dress. Its specific arrangement on the other hand expresses the possibility of overcoming the traditional ways, and the demonstration of wealth and individuality. The females which were equipped with such dresses were all placed in one area in the cemetery (Reinhold 1997:169-172, Fig. 13).

A similar process as at Lugovoe can be observed at other sites in Chechenia and also in the area of Kislovodsk and Pyatigorsk (Reinhold 2002:387, 398). But unlike in Chechenia, the development of social groups that bury their deceased members in costumes which overcome traditional classification systems is a phenomenon which is not an intra-site development, but one from site to site. The graveyards reflect either communities with traditional structuring principles or those with the new practices. Only the communities of the high mountain area around Koban and Tli seem not to have participated in this transformation. Here changes in costumes are visible during the later Iron Age, but with the exception of the introduction of neck-rings, they are restricted to typological variations.

If we look at the geographical distribution of the late Iron Age costumes we cannot make out costume areas at all. The distribution of specific types of rich costumes, for example, ornamented belt plates or double pins with chains, now encompasses much larger areas (Kozenkova 1979: map).

Summing up, we can state that female costumes of the late Bronze Age/early Iron Age in the northern Caucasus indicate a classification of the person wearing them according to horizontal categories like gender, age or status, rather than in vertical structures like wealth or prestige. This evidence can be supported using comparative analyses for these graves, which include both the other burial gifts and the expenditure on tomb construction (Reinhold 1996:198-200, Fig. 9, 1997:169-170; for the methodology see Freudenberg 1989:43-49; Jørgensen 1990:63-64). At Serzen'-Jurt increases in the relative wealth of the grave inventories correlate with the costume classes. Although there is a clear ranking of wealth among the different levels, within each level there is nearly no variation. Furthermore, the existence of equally ranked and categorized women in all grave groups from Serzen'-Jurt indicates a similar internal structure for all the groups families? - buried there (Fig. 6.1). At the later Lugovoe cemetery, the situation is different: here wealth increases over time in only one group. The other two groups become poorer (Reinhold 1997, Fig. 13).

A second phenomenon regarding burial costumes in the northern Caucasus is a notable geographical change. The costumes of the first period discussed indicate small-scale micro-regional entities with accepted rules of dress. During the second phase, no costume areas can be reconstructed, but some of the costumes can be found over a larger geographical area than before. These specific costumes are represented by only one or two individuals at each site. It is not surprising that these are also the wealthiest female burials like the wearers of double-axe shaped belt-plates at Lugovoe, Istri Su and elsewhere.

A third aspect in the development from the late Bronze Age/early Iron Age to 
the more recent period concerns the character of the costume structures. During the first period women's dress - or their burying community - were restricted in composition, general appearance and details. This indicates a strong tradition and a conservatism that prevents variation. During the second period this traditional restriction changed, and there was a remarkable change to more individual arrangements. Presumably we observe here the transformation of a traditional model of society where social identities could only be expressed in a ranked and very formal way, to a society where more individual freedom was possible and some groups could overcome the traditional way of burial. Whoever the performers of this individuality may have been, their influence must have been large enough to impose their interests on their communities, despite traditional rules.

\section{WARRIOR GRAVES - MALE COSTUMES AND ARMAMENT}

The male graves at the sites of the Koban culture are usually equipped with arms or tools. The assemblages of arms can be analysed in the same way as the female burial costumes, since they are created in a similar manner. Weapons including daggers, axes and lances and tools are combined in a distinctive arrangement of weapons (or 'armament'), which can be placed beside the costumes (Sharafutdinova 1993:58-59; Reinhold 1996, 1997; Leskov and Erlich 1999:31-33).

For the earlier period we will focus once more on the site of Serzen'-Jurt (Fig. 10, A-D). There we find a very similar display of social identities in the armament to that described for females. In the graves the arms are combined in characteristic weapon combinations (Fig. 11), which express a ranked structure like the female costumes (Reinhold 1996, 1997). The basic assemblage is just a dagger without further weapons or equipment (Fig. 10, C-D). The combination of this dagger with an axe or a lance forms a second group (Fig. 10, B), and an armament with dagger, axe and lance a third. At the top of the scale we find a fourth group of five graves with more arms than could be used by a single person (Fig. 10, A). At the lower end we have a fifth and a sixth class of graves without arms, those furnished only with knives and those of unarmed males. The last group is identified by the presence of single bracelets, which is a typical feature of armed individuals (Reinhold 1997:165, Fig. 3, 2002:385). In the male sphere a categorization into armed and unarmed males can therefore be recognized. The group of warrior graves furthermore demonstrates sophisticated ranking by the number and different weapon types. Although the combination of weapons allows the reconstruction of characteristic armament groups, their typological aspect is more individual than in the ornaments of the female costumes. The weapons show a broad spectrum of different types, including imported items (Kozenkova 1992).

An interpretation of the different arms assemblages as representations of warrior status is as problematic as the interpretation of the female costumes. The number of graves in each class is approximately the same: 49 per cent of the male individuals of Serzen'-Jurt are armed, 40 per cent are not armed and 11 per cent of the graves included only tools. Among the warrior graves 13-18 per cent belong to 


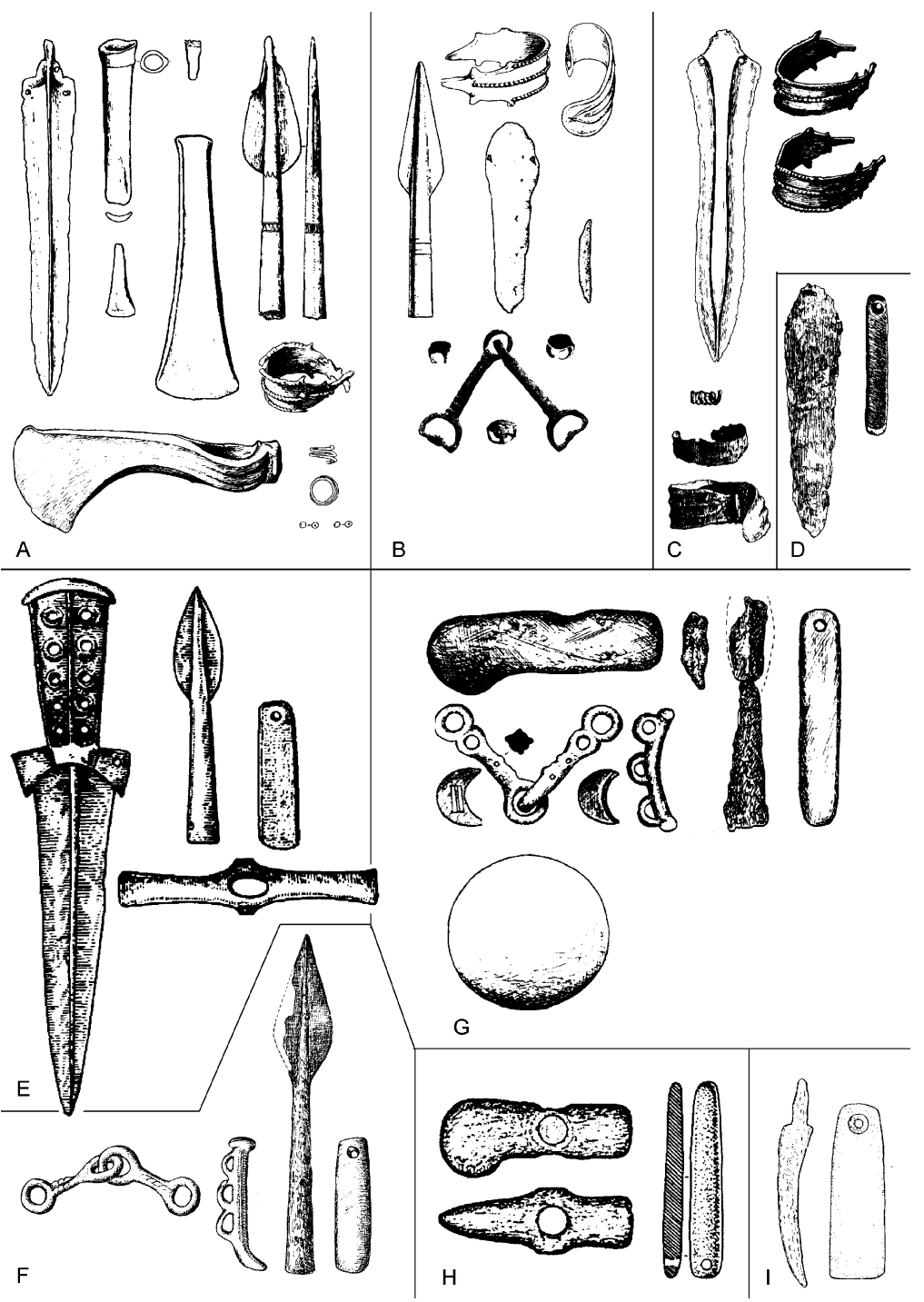

Figure 10. Late Bronze Agelearly Iron Age warrior graves from Serzen'-Jurt ( $A-D$, after Kozenkova 1992) and Kislovodsk (E-I, after Dudarev 1999). Ceramic material omitted.

$\mathrm{A}=$ Serzen'-Jurt, grave 42; $\mathrm{B}=$ grave $39 ; \mathrm{C}=$ grave $57 ; \mathrm{D}=$ grave $87 ; \mathrm{E}=$ KislovodskMebel'naja fabrika, grave 26; $\mathrm{F}=$ Kislovodsk-Belorecenskij 2, grave 33; $\mathrm{G}=$ KislovodskKlin Jar 3, grave 21; $\mathrm{H}=$ Kislovodsk-Sultan gora 1, grave 10; $\mathrm{I}=$ Kislovodsk-Industrija, grave 14. Scale: $\mathrm{A}-\mathrm{D} \approx 1: 7, \mathrm{E}-\mathrm{F} \approx 1: 5, \mathrm{H}-\mathrm{I} \approx 1: 3$.

each of the different armament groups. This, and the regular distribution of all armament groups in all grave groups (Fig. 6.2) indicates a non-vertical ranking according to warrior or age classes, rather than one based on the status or prestige of a family. But unlike the female costumes, an individual component in the 


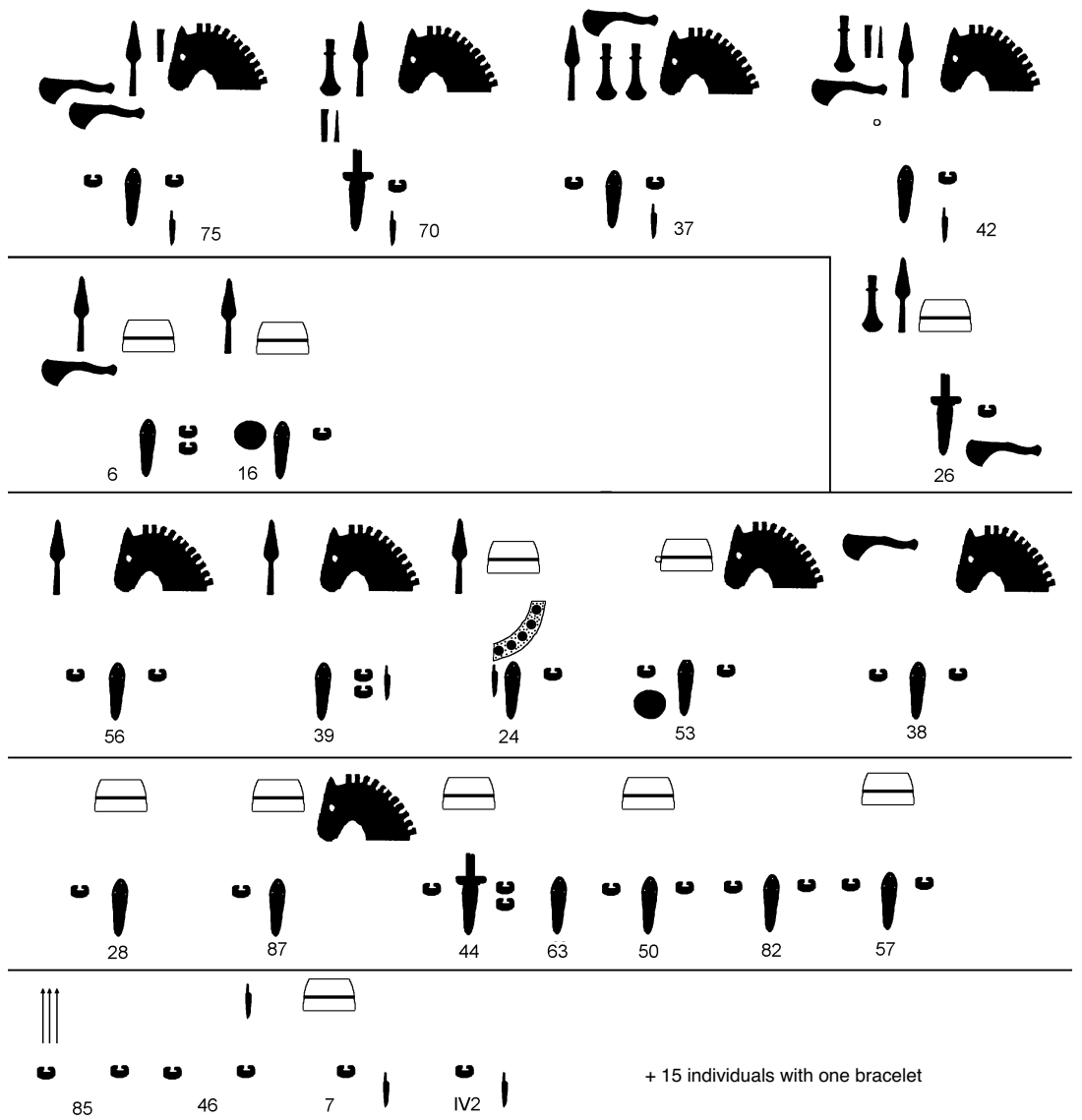

Figure 11. Serzen'-Jurt-armament.

warrior graves, expressed by the choice of typologically different weapons and the multilevelled classification system of armament is present. It indicates perhaps a less strict syntax in the expression of male identities through material objects than in the female sphere. The individual note of the warrior graves at Serzen'-Jurt is also demonstrated by the offering of riding horses in nearly a quarter of these burials. At first sight they seem to contradict the suggested horizontal ranking. Kozenkova (1992:70-74) and others, for instance, consider the horses as signs of rank and wealth of the buried individuals. But there is no correlation between armament group or richly furnished graves and horse burials (Fig. 6.2 and Fig. 11). Obviously the sacrifice of a horse was neither relevant to a specific mounted warrior class, nor necessarily combined with wealth. Perhaps it marks an element in the male funerary ritual where private possession or, for instance, the incorporation into a specific group in society connected with horses was displayed.

The cemeteries in the western area of the Koban culture around Kislovodsk and 
Pyatigorsk reveal a similar expression of social identities in armament as in the east. Yet here the number of excavated graves per site is smaller, so structures are less apparent. Combinations of daggers, axes and lances form similar armament groups as discussed earlier. Here, too, a class of unarmed males equipped with tools is present (Reinhold 2002:395-396). The presence of horse gear is very typical for warrior graves in the central and north-western piedmont zone of the Caucasus. Most scholars therefore classify the males of these communities primarily into mounted and unmounted warriors with a distinctive vertical hierarchy (Kossack 1994:32; Dudarev 1999:170-179; Leskov and Erlich 1999:32-33, 90). The classification by armament, however, again shows no correlation with horse gear (Reinhold 2002:395, Figs 166-172). As at Serzen'-Jurt, both criteria seem to express different levels of social identities. The strong evidence of horsemanship in the central and western groups may be linked to a steppe-like landscape suitable for breeding horses or by different burial concepts as in the eastern group.

In the mountain area, at sites like Tli and Koban, the armament includes only axes and daggers (Teržan 1995; Reinhold 2002:406-407, Fig. 188). Lances are extremely rare, and horse-harness is almost absent. With the decrease in variables, the variation in the armament is reduced as well. In the pre-Scythian period, we find only a variation in the numbers of axes and daggers. Nevertheless, this makes a ranking similar to the regions discussed earlier obvious, and, interestingly, the warriors with combined armament are always dressed with a bronze belt and a fibula, while the graves with only one weapon also lack belt or fibula (Reinhold 2002): unlike in the other micro-regions, here identities displayed by weapons are also reflected in the male burial costumes.

Weapon combinations including dagger, axe, lance and horse-harness as basic armament are found in the entire piedmont zone of the northern Caucasus (Fig. 10). The groups in the mountains and in Transcaucasia in contrast used only axes and daggers as their armament. The large geographical coverage of armament classes is associated with a wider geographical distribution of the particular types. There are usually core areas in artefact distribution, but most weapon types display a widespread distribution (Figs 12.1 and 12.2). Weapon exchange is evident across the entire area of the Koban culture (Kozenkova 1992; Reinhold 2002:432-440). This exchange of arms and equipment is confirmed by metallurgical analyses. Central Caucasian types are found in all areas on the northern slope (Fig. 12.1). Western types are distributed as far as the high mountain valleys or Chechenia (Fig. 12.2). They have also a wide distribution across the Eurasian steppe towards the west (Reinhold 2002; Dudarev 1999). The male sphere of the pre-Scythian late Bronze Age/ early Iron Age reveals a large-scale network of interlinked communities which not only exchanged arms but also share similar ways of expressing their social identities.

Unlike the female costumes, at the beginning of the late Iron Age these similarities in armament became even more wide-ranging. In all geographical groups a single lance in combination with a knife dominates the weapon assemblages. The use of axes and daggers, both now under strong Scythian typological influence, decreases. Once more we return to Lugovoe, the cemetery 


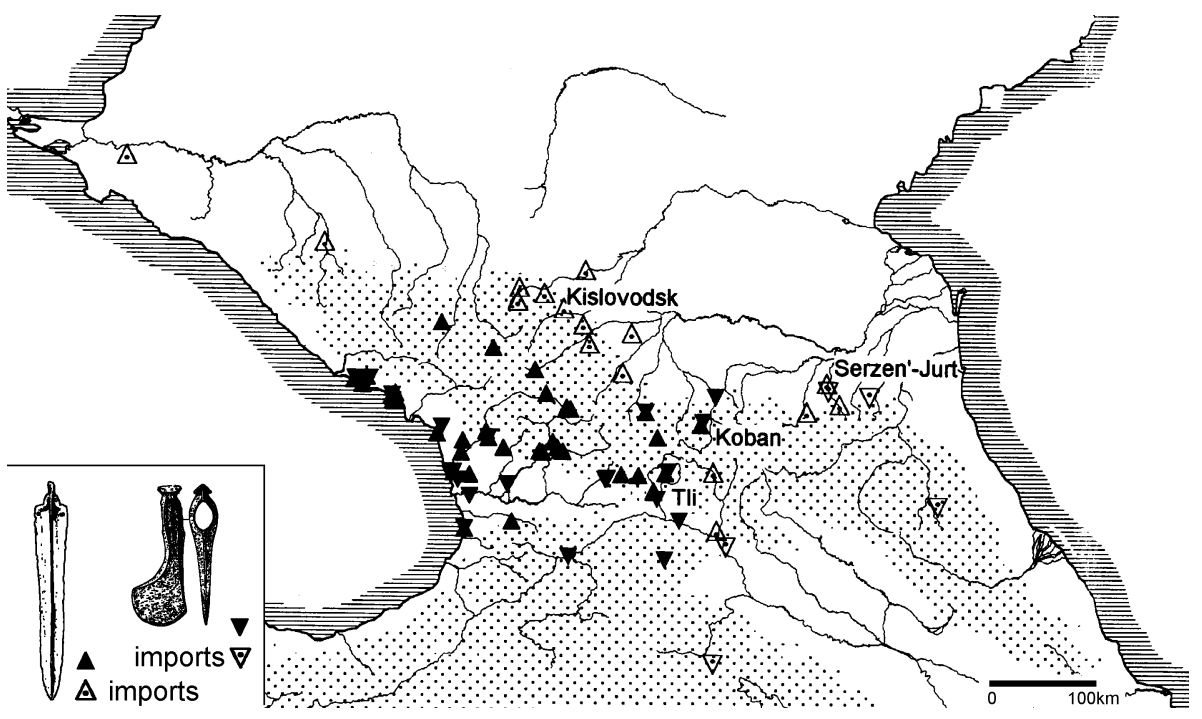

$\because \quad$ Land above $1000 \mathrm{ft}$

Figure 12:1. Distribution of central Caucasian arms. Black triangles indicate areas of main distribution, outline triangles indicate imports from the core areas.

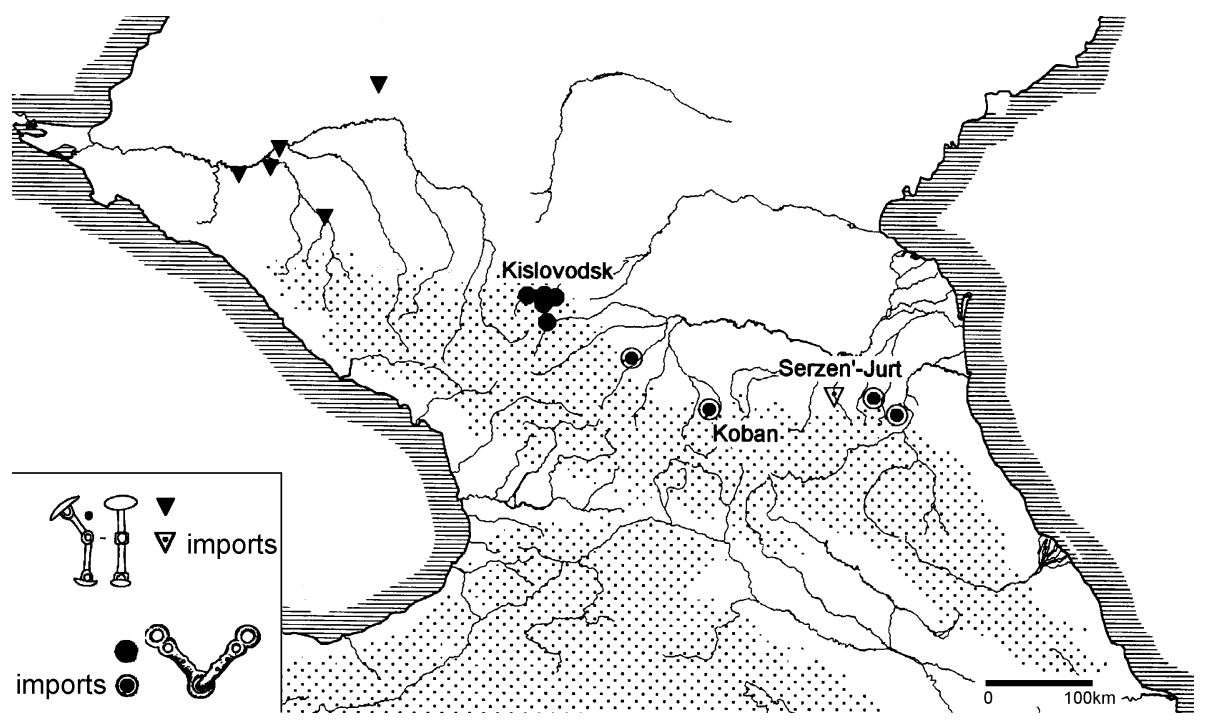

$\because$ Land above $1000 \mathrm{ft}$

Figure 12:2. Distribution of north-west Caucasian horse harness. 
used during the late Iron Age. Here during the first chronological phase no weapons other than lances are used at all (Fig. 8). They are regularly combined with knives. In the Kislovodsk and Pytigorsk area the lance/knife combination prevails in cemeteries of the later period, like Ullubaganaly (Kovalevskaja 1984) or Karras. In sites with a tradition from the pre-Scythian period dagger/lance combinations in addition to bow and arrow dominate (Reinhold 2002:396).

During the last phase of the late Iron Age a further transformation took place. It is most explicit in several elaborate, individual and very wealthy graves at Lugovoe. There, combinations of several axes, daggers/akinakai, bow and arrow and horse gear form a group of grave inventories which stand beside the usual lance/knife combination. And again the complex armament is correlated with an increase in relative wealth and the placement in the same grave group as the elaborate female dresses (Reinhold 1996:198, Fig. 13).

\section{Traditions in transition - a Bronze Age/Iron Age view from the Caucasus}

The late Bronze Age and the Iron Age costumes and armament of the north Caucasian groups reflect a notable transformation over a period of nearly one millennium. While clear categories in costume or armour signified the social identities of the late Bronze Age/early Iron Age individuals, the late Iron Age is characterized by more individual dress and armament, an increase of social fission along vertical criteria like wealth and a differentiation in group identities. The older burial concept focused on corporate identities that divided the members of a community into social classes. The more recent burial concept indicates a shift to group rather than corporate identities. This shift happens rather slowly and can be traced as a general phenomenon only during the last phases of the Iron Age somewhere in the fifth century BC. In places like Serzen'-Jurt, however, a similar phenomenon marks the end of the cemetery's use during the first phase of Scythian influence (Kozenkova 1992). The most elaborate and rich graves at this site belong to a group which is localized a little apart from the main graveyard (Figs 6.1 and 6.2). They display a deliberate breach with older traditions, a strong Scythian influence in material culture (Fig. 9, A and B) and also a vertical fissure into very rich and rather poor graves. Therefore, the overall phenomenon of a shift from corporate identities to smaller group identities is in some places evident much earlier than the fifth century BC.

As well as the beginning of the change in burial concepts after the establishment of early Scythian groups in the steppe to the north of Caucasian piedmonts (Machortych 1991; Kovalëv 1998) the Serzen'-Jurt example raises the question as to whether the transformation was the result of a general development from Bronze Age to Iron Age societies or rather that of an external cultural influence. Yet, the intensity of Scythian influence in the northern Caucasus remains an open question. Some models suppose only some cultural influence on the local population (Machortych 1991; Kozenkova 1996:101-103), others suggest the existence of a Scythian kingdom in the north Caucasian foothills during the seventh century BC. 
The material culture of the entire north Caucasian piedmont zone, however, is distinctively influenced by objects in Scythian style. But here also it is not clear to what extent the new style is imported or is the result of a mixture of Scythian style, local types and local technological skills (Terechova 1997:48-78). The areas of Scythian kurgan cemeteries which were established at the beginning of the later Iron Age are generally separated from the local sites and situated predominately in steppe environments. They include a large number of extremely rich burial mounds as at well-known sites like Kelermes (Galanina 1997). Nearly all the graves excavated from these sites are rich in armament, gold ornaments, imported objects, horse harness and horse burials, and demonstrate a considerable expenditure in constructing large burial monuments. Furthermore, levels in wealth of the burial equipment and the size of the mounds indicate a hierarchical social structure, which is also confirmed by the early written sources about Scythians, predominately Herodotus (Galanina 1997). A cultural influence by Scythian tribes could therefore have been the origin of the transformation in local burial concepts, which presumably reflect a shift in social organization.

On the other hand, recent studies of Bronze Age and Iron Age burial costumes and associated social structure in Central Europe indicate a very similar transformation. During the middle Bronze Age (Tumulus Culture) in Central Europe, Wels-Weyrauch (1989:117-134, 1993:30-36; see also Sørensen 1997: 105-109) met with burial costumes very similar in expense, visibility and structure. Even the size of the territories in which a similar costume was worn is similar to the Caucasian late Bronze Age/early Iron Age costume areas. Male armament including adzes and daggers are as widespread as the distribution of specific types. During the following the Urnfield period which is approximately contemporary with the Caucasian late Bronze Age, cremation makes costume analysis difficult. Sørensen (1997) postulates a subsequent shift to more standardized, less elaborate costumes during the late Bronze Age. Her conclusion for the evaluation of costumes at the end of the Bronze Age is 'that either costumes became less significant in the communication and maintenance of social identities, that different aspects of identity were becoming more important, or that other, less durable elements of appearance were emphasised' (Sørensen 1997:109). In the Hallstatt period, contemporary with the early Iron Age and the first chronological phase of the late Iron Age in Caucasia, social fission expressed in burial equipment definitely increased. After a prelude in Hallstatt $C$ that sees the emergence of a warrior class with swords and wagons across Europe (Pare 1992), during the late Hallstatt period burial costume and armament are used to express social ranks and local identities in a very elaborate way. In his study of late Hallstatt burials from southern Germany, Burmeister (2000) demonstrates that criteria like gender and age still dominate the social identities expressed in graves. Beside that, however, hierarchical ranking within age and gender groups is evident through the quality of burial goods. At the top of these communities we find the so-called princely graves which indicate a much stronger vertical ranking than during the Bronze Age. Female costumes in the late Hallstatt period also reflect similar structures to 
those described for the later Caucasian sites like Lugovoe. They include some general features but a multilevelled categorization and a division with widely distributed items and strong local variation for the other types (Müller 1994a).

In my view the Caucasian development reflects this general shift that I have outlined to more hierarchically structured societies and smaller territorial identities at the transition from the Bronze to the Iron Age, rather than a strong external influence. The Scythian impact on the local Caucasian societies should not be denied, but it seems to have been rather superficial and did not immediately change the traditional social structures. The Caucasian development is similar to the overall trend at the beginning of the Iron Age, but it also shows differences. With two exceptions from the western Kuban area, no princely graves are recognizable among the north Caucasian cemeteries. At least in the graves, chiefs were not marked by special equipment. In the northern Caucasus we cannot trace either the development of a princely stratum or any kind of territorial centralization until the early medieval period. The gender/age-based society of the Bronze Age habitus departed, and in its place the hierarchical society in the 'Iron Age manner' appeared.

\section{ACKNOWLEDGEMENTS}

This article was first presented in 1998 as a paper at the EAA Annual Meeting in Bournemouth. It summarizes some results of my MA thesis on the north Caucasian Koban Culture which was submitted at the Institut für Prähistorische Archäologie, Freie Universität Berlin. I would like to thank my supervisors, Professor B. Hänsel and Professor B. Teržan, and all who have contributed to this article, both the present text and the previous version, by their critical comments, hints and new considerations. I am also grateful to the two anonymous referees who made useful suggestions.

\section{Notes}

1. The archaeological objects from the northern Caucasus, especially those from Serzen'Jurt, Kislovodsk and Koban, which, thanks to V.I. Kozenkova, A.P. Mozhinskij (Moscow), S.L. Dudarev, J.B. Berezin (Armavir/Kislovodsk) and A. Heinrich (Vienna), I was able to examine, show heavy use-wear. This also suggests their use during the lifetime of their owners.

2. In the theoretical part of this essay I will use this German term, when speaking about formal - but not ritual - dress in general. Unlike the English counterparts 'dress' or 'costume' it denotes exactly the traditional, normative and social significance of the clothes worn. Nothing in Tracht is without symbolic significance. It therefore seems to me a better term than either 'dress', which is too general, or 'costume', which implies a ritual, ceremonial character. In the later part, dealing with the archaeological material from burials, one can of course assume a ritual character, and the term 'costume' will be used. For a detailed discussion of the English terms see also Eicher and Roach-Higgins 1992:12-19 and Sørensen 1997:95-96.

3. For the pre-modern Caucasus the male/female difference can be seen in language as well as dress. While most of the males had been integrated into a system of interregional seasonal migrations, women more often stayed in the villages. Consequently most males 
spoke several languages, while the females only spoke the local dialects (Wixman 1980:58-59).

4. This ethnographical evidence can be confirmed for the Caucasian case study by the heavy use-wear mentioned ealier (see note 1) which strengthens the argument that these burial costumes can indeed be regarded as remains of a Tracht used in life.

5. Characteristic features at late medieval cemeteries are for instance the so-called 'bridal crowns' which should indicate the dead girl's marriageable status.

6. The definition of the territory of the Koban culture varies according to different authors: Kozenkova (1996:62-73, Fig. 26), an older scholar, restricts it to the central and eastern parts of the northern Caucasus, while several younger authors, including me, argue for a larger cultural koiné which also includes the north-west Caucasian Protomaeotic culture and the west Georgian Kolchis culture.

7. The determination of sex at Tli is based on the notes in the excavation reports. At Koban only 20 burials can be reconstructed as complexes. An anthopological determination is given only as male/female.

8. There is unfortunately much less anthropological data for these sites than for Tli. At Serzen'-Jurt no anthropological examination of the bones was possible because of the very bad preservation of the skeletal material (pers. com. V.I. Kozenkova). The older Kislovodsk material was obviously classified by a physician (pers. com. D.S. Korobov, Moscow). The newly excavated graves from Klin Jar (Dudarev and Berezin 1999; Härke and Belinskij 2000) are classified anthropologically, but the data have not yet been published.

9. It should be noted that the plan includes graves from all four chronological phases which are not equally distributed. The western group ends during the second phase and the most easterly group includes only graves from the last chronological stage. In the central grave groups we find graves from the first three periods in varying percentages.

\section{REFERENCES}

ANGELI, WALTER, 1991. Der ethnologische Ethnosbegriff und seine Anwendung in der Prähistorie. Mitteilungen Anthropologische Gesellschaft Wien 121:189-202.

BAKer, PAtricia L., 1997. Politics of Dress: the Dress Reform Laws of 1920-1930s Iran. In Nancy Lindisfarne-Tapper and Bruce Ingham (eds), Languages of Dress in the Middle East: 178-192. Richmond: Curzon Press.

Bogatyrev, Petr, 1971. The Function of Folk Costume in Moravian Slovakia. The Hague and Paris: Mouton.

BOURDIEU, PIERRE, 1976. Entwurf einer Theorie der Praxis auf ethnologischen Grundlagen der kabylischen Gesellschaft. Frankfurt/M.: Surkamp.

Bulst, NeITHARD, 1993. Kleidung als sozialer Konfliktstoff. Probleme kleidergesetzlicher Normierung im sozialen Gefüge. Saeculum 44(1):32-46.

BurMEISTER, STEFAN, 1997. Zum sozialen Gebrauch von Tracht. Aussagemöglichkeiten hinsichtlich des Nachweises von Migrationen. Ethnologisch-Archäologische Zeitschrift 38:177-203.

BURMEISTER, STEFAN, 2000. Geschlecht, Alter und Herrschaft in der Späthallstattzeit Württembergs. Münster, New York, München and Berlin: Waxmann.

BURSTRÖM, MATS, 1996. Reconstructing the spatial extension of ancient societies. A Scandinavian Viking Age example. Archaeologia Polona 34:165-182.

Chenciner, Robert, 1997. Felt capes and masks of the Caucasus. In Nancy Lindisfarne-Tapper and Bruce Ingham (eds), Languages of Dress in the Middle East: 80-92. Richmond: Curzon Press.

CHERNYKH, EvgEnI, 1992. Ancient Metallurgy in the USSR. Cambridge: Cambridge University Press.

DudAREV, SERGEj L., 1999. Vzaimootnošenija plemen Severnogo Kavkaza s kočevnikami 
Jugo-Vostočnoj Evropy v predskifskuju epochy (IX - pervaja polovina VII v. do n.é.). Armavir.

Dudarev, Sergej L. and Jakov B. Berezin, 1999. Neue präskythische Funde aus der Umgebung von Pjatigorsk, Nordkaukasien. Eurasia Antiqua 5:177-209.

Eicher, JoAnNe B. and Mary-Ellen RoACh-Higgins, 1992. Definition and classification of dress: implications for analysis of gender roles. In Ruth Barnes and Joanne B. Eicher (eds), Dress and Gender. Making and Meaning: 8-28. Providence, RI and Oxford, UK: Berg.

Eicher, JoAnNe B. and TONEY V. EREKOsima, 1995. Why do they call it Kalabari? Cultural authentication and the demarcation of ethnic identity. In Joanne B. Eicher (ed.), Dress and Ethnicity: 139-164. Oxford: Berg.

FreudenBerg, MechtiLD, 1989. Studien zur vertikalen sozialen Struktur. Eine Analyse der Grabfunde der jüngeren Bronzezeit in Dänemark. Oxford: British Archaeological Reports (International Series 524).

Galanina, LuDmilla K., 1997. Die Kurgane von Kelermes. 'Königsgräber' der frühskythischen Zeit. Steppenvölker Eurasiens 1. Moskau: Institut für allgemeine Geschichte der Russischen Akademie der Wissenschaften, Zentrum für Erforschung Studien der alten Zivilisationen.

GERndT, H., 1974. Kleidung als Indikator kultureller Prozesse, Eine Problemskizze. Schweizer Archiv für Volkskunde 70:81-92.

Grainger, Roger, 1998. The Social Symbolism of Grief and Mourning. London: Jessica Kingsley.

HÄRKE, HeINRICH, 1993. Intentionale und funktionale Daten. Ein Beitrag zur Theorie und Methode der Gräberarchäologie. Archäologisches Korrespondenzblatt 23:141-146.

HÄRKE, HEINRICH, 1997. The nature of burial data. In Claus Kijld Jensen and Karen Høilund Nilsen (eds), Burial and Society. The Chronological and Social Analyses of Archaeological Burial Data: 19-27. Aarhus: Aarhus University Press.

HÄRKE, HeInRICH and ANDREJ B. BeLINSKIJ, 2000. Nouvelles Fouilles de 1994-1996 dans la necropole de Klin-Yar. In Michel Kazanski and Vanessa Soupault (eds), Colloquia Pontica. Les sites archéologiques en Crimée et au Caucase durant l'antiquité tardive et le haut Moyen-Age: 194-210. Leiden: Brill.

HODDER, IAN, 1982. The identification and interpretation of ranking in prehistory: a contextual perspective. In Colin Renfrew and Steven Shennan (eds), Ranking, Resource and Exchange: 150-154. Cambridge: Cambridge University Press.

JARITZ, GERHARD, 1993. Kleidung und Prestige-Konkurenz. Unterschiedliche Identitäten in der städtischen Gesellschaft unter Normierungszwängen. Saeculum 44(1):8-31.

JøRGENSEN, LARS, 1990. Bækkegård and Glasergård. Two Cemeteries from the Late Iron Age on Bornholm. København: Akademisk Forlag.

KANN, P., 1982. Trachten bolivianischer Hochlandindianer. Schweizer Archiv für Volkskunde 36:37-58.

Кововоv, D.S., 2001. Nekotrye itogi rabot Kislovodskogo archeologičeskogo otrja a v 1996-1999 gg. In Aleksander S. Smirnov (ed.), Praktika $i$ teorija archeologičeskich issledovanij: 44-55. Moscow: Nauka.

KORYAKOVA, LuDMILA, 1996. Social trends in temperate Eurasia during the second and first millennium BC. Journal of European Archaeology 4:243-280.

KosSACK, GEORG, 1994. Neufunde aus dem Novočerkassker Formenkreis und ihre Bedeutung für die Geschichte steppenbezogener Reitervölker der späten Bronzezeit. Il Mare Nero 1:19-54.

KOVALËV, AlEKSANDER, 1998. Überlegungen zur Herkunft der Skythen aufgrund archäologischer Daten. Eurasia Antiqua 6:247-271. 
Kovalevskaja, Vera B., 1984. Kavkaz i Alany. Moscow: Nauka.

KozenKOVA, VAlentinA I., 1977. Kobanskaja kul'tura. Vostočnij variant. Archeologija SSSR. SVOD Archeologičeskich istočnikov, V2-5. Moscow: Nauka.

KozenKova, VAlEnTINA I. 1979. Predmety iz Za-Vedeno (Chechno-Ingushetija) serediny I tysjačeletija do n. è. In Kavkaz $i$ Vostočnaja Evropa $v$ drevnosti: 149-158. Moscow: Nauka.

KozenKova, VALENTINA I., 1989. Kobanskaja kul'tura. Zapadnij variant. Archeologija SSSR. SVOD Archeologičeskich istočnikov, V2-5. Moscow: Nauka.

KozenKOVA, VAlentiNA I., 1990. Chronologija kobanskoj kul'tury: dostiženija, opyt utochenija, nerešennye problemy. Sovetskaja Archeologija 1990(4):64-92.

KozenKova, Valentina I., 1992. Serzen Jurt. Ein Friedhof der späten Bronze und frühen Eisenzeit im Nordostkaukasus. Mainz: Philipp von Zabern.

KozENKOVA, VAlENTINA I., 1996. Kul'turno-istoričeskie processy na Severnom Kavkaze $v$ epochu pozdnej bronzy $i$ v rannem železnom veke (Uzlovye problemy proischoždenija i razvitnaja kobanskoj kul'tury). Moscow: Nauka.

KRISTIANSEN, KRISTIAN, 1994. The emergence of the European World System in the Bronze Age: Divergence, convergence and social evolution during the first and second millennium BC in Europe. In Kristian Kristiansen and Jørgen Jensen (eds), Europe in the First Millenium BC: 7-30. Sheffield: J.R. Collis Publications.

KRISTIANSEN, KRISTIAN, 1998. Europe before History. Cambridge: Cambridge University Press.

Leskov, Alexandr M. and Vladimir R. Erlich, 1999. Mogil'nik Fars/Klady. Pamjatnik perechoda ot epochi pozdnej bronzy $k$ rannemu železnomu veku na Severo-Zapadnom Kavakze. Moscow: Gosudarstvennym Muzej Vostoka.

LINDISFARNE-TAPPER, NANCY, 1997. The dress of Shasevan tribespeople of Iranian Azerbaijan. In Nancy Lindisfarne-Tapper and Bruce Ingham (eds), Languages of Dress in the Middle East: 67-79. Richmond: Curzon Press.

MACHORTYCH, SERGej V., 1991. Skify na Severnom Kavkaze. Kiev: Naukova Dumka.

MiKlaUtZ, ElFIE, 1996. Der kristallisierte Sinn. Ein Beitrag zur soziologischen Theorie des Artefakts. München/Wien: Profil.

MüLlER, JOHANNES, 1994a. Zur sozialen Gliederung der Nachbestattungsgemeinschaft vom Magdalenenberg bei Villingen. Prähistorische Zeitschrift 1994(2):175-221.

MÜLLER, JOHANNES, 1994b. Bestattungsformen als Spiegel dualer Organisation in prähistorischen Gesellschaften? Mitteilungen Berliner Gesellschaft Anthropologie, Ethnologie, Urgeschichte 15:81-88.

Munchaev, RAuF M., 1963. Lugovoeskij mogil'nik. In E.I. Krupnov (ed.), Dreonostij Ččeno-Ingušetija: 139-211. Moscow: Nauka.

NorTON, JOHN, 1997. Faith and Fashion in Turkey. In Nancy Lindisfarne-Tapper and Bruce Ingham (eds), Languages of Dress in the Middle East: 149-177. Richmond: Curzon Press.

PADER, Ellen-JANE, 1982. Symbolism, Social Relations and the Interpretation of Mortuary Remains. Oxford: British Archaeological Reports (International Series 130).

PARE, Christopher F.E., 1992. Wagons and Wagon Graves of the Early Iron Age in Central Europe. Oxford: Oxford University Committee for Archaeology.

PARKER-PEARSON, Michael, 1982. Society and archaeology: an ethnoarchaeological study. In Ian Hodder (ed.), Symbolic and Structural Archaeology: 99-113. Cambridge: Cambridge University Press.

ReINHOLD, SABINE, 1996. Time versus ritual - typological structures and mortuary practices in late Bronze Age/early Iron Age cemeteries of north-eastern Caucasia ('Koban Culture'). In Hans Kammermans and Kelly Fennema (eds), 
Interfacing the Past. Computer Applications and Quantitative Methods in Archaeology CAA95: 195-202. Leiden.

ReINHOLD, SABINE, 1997. Zeit oder Sozialstruktur? Bemerkungen zur Anwendung von Korrespondenzanalysen bei der Untersuchung prähistorischer Grabfunde. In Johannes Müller and Andreas Zimmermann (eds), Archäologie und Korrespondenzanalyse. Beispiele, Fragen, Perspektiven: 161-174. Espelkamp: Marie Leidorf.

REINHOLD, SABINE, 2002. Untersuchungen zur späten Bronze und frühen Eisenzeit im Kaukasus. Materielle Kultur, Chronologie, Fernkontakte. Unpublished $\mathrm{PhD}$ thesis, Berlin (in preparation).

SCHÜlKe, Almut, 1999. On Christianization and grave-finds. European Journal of Archaeology 2(1):77-106.

SHARAFUTDINOVA, E.S. 1993. O social'noj granicii v protomeotskom pogrebal'nom obrjade. Kratkie Soobšenija (Moscow) 203: 54-62.

SOFAER DEREVENSKI, JOHANNA, 1997. Linking age and gender as social variables. Ethnologisch-Archäologische Zeitschrift 38:485-493.

Sørensen, MARIE-LOUISE STIG 1997. Reading dress: the construction of social categories and identities in Bronze Age Europe. Journal of European Archaeology 5(1):93-114.

StOcchia, SHARON T., 1992. Death and Ritual in Renaissance Florence. Baltimore, MD and London: Johns Hopkins University Press.

TAINTER, J.A., 1978. Mortuary practices and the study of prehistoric social systems. In Michael B. Schiffer (ed.), Advances in Archaeological Method and Theory 1: 106-141. New York, London: Academic Press.

TAYLOR, LOU, 1983. Mourning dress. A Costume and Social History. London: Gerorge Allen and Unwin.

TeCHOV, B.V., 1980. Tlijskij mogil'nik 1. Tbilisi: Mecinereba.

TeCHOV, B.V., 1981. Tlijskij mogil'nik 2. Tbilisi: Mecinereba.

Techov, B.V., 1985. Tlijskij mogil'nik 3. Tbilisi: Mecinereba.

TERECHOVA, N.N., 1997. Rannie etapy razvytija železoobrabotka v Vostočnoj Evrope. In N.N. Terechova, L.S. Rosanova, V.I. Zav'jalov and M.M. Tolmačeva (eds), Očerki po istorii drevnej železoobrabotki v Vostočnoj Evrope. Moscow: Metallurgija: 30-78.

TerŽAN, BIBA, 1995. Das Land der Medeia? In Uwe Finkbeiner, Rainer Dittman and Harald Hauptmann (eds), Beiträge zur Kulturgeschichte Vorderasiens. Festschrift R.M. Böhmer: 627-637. Mainz: Phillip von Zabern.

TREHERnE, PAUL, 1995. The warrior's beauty: the masculine body and self identity in Bronze Age Europe. Journal of European Archaeology 3(1):105-144.

VAn GenNeP, ARnOld, 1960. The Rites of Passage. London: Routledge and Keagan Paul (first published 1909).

VeIT, UlRICH, 1997. Tod und Bestattungssitten im Kulturvergleich. Ethnoarchäologische Perspektiven einer 'Archäologie des Todes'. Ethnologisch-Archäologische Zeitschrift 38: 291-314.

VinOGRADOV, V.B. and DuDAREV, SERGEJ L., 2000. Spätbronzezeitliche Gräberfelder bei Majrtup in Čečenien. Eurasia Antiqua 6:361-403.

Wels-WeYRAUCH, UlRIKe, 1989. Mittelbronzezeitliche Frauentrachten in Süddeutschland (Beziehungen zur Hagenauer Gruppierung). In Dynamique du Bronze Moyen en Europe Occidentale. Actes du 113e congrès national des sociétes savantes, Strasbourg 1988: 117-134. Strasbourg.

Wels-Weyrauch, UlRiKe, 1993. Das trug die Frau von Welt. Bronzezeitliche 'Mode' im Wiesbadener Raum. In 200000 Jahre Kultur und Geschichte in Nassau: 29-40. Wiesbaden: Verlag des Vereins für Altertumskunde und Geschichtsforschung. 
Welters, Linda, 1995. Ethnicity in Greek dress. In Joanne B. Eicher (ed.), Dress and Ethnicity: 53-78. Oxford: Berg.

WIXMAN, RONALD, 1980. Language aspects of ethnic patterns and processes in the northern Caucasus. Chicago, IL: The University of Chicago Department of Geography.

YAMANI, D., 1997. Changing the habits of a lifetime: the adaptation of Hejazi dress to the new social order. In Nancy Lindisfarne-Tapper and Bruce Ingham (eds), Languages of Dress in the Middle East: 55-66. Richmond: Curzon Press.

\section{BIOGRAPHICAL NOTE}

Sabine Reinhold has recently finished her PhD in archaeology at the Freie Universität Berlin with a thesis entitled 'Studies of Late Bronze Age and Iron Age in the Caucasus material culture, chronology, interregional contacts'. For five years she has been a speaker at the German Theoretical Archaeological group and is interested in archaeological theory and the conception of territorial analysis in archaeology. Address: Institut für Prähistorische Archäologie, Freie Universität Berlin, Altensteinstraße 15, 14195 Berlin. [email: sabine_reinhold@hotmail.com]

\section{Abstracts}

Traditions en transition : quelques réflexions sur les costumes funèbres de la fin de l'âge du bronze et du début de l'âge du fer en Caucase du Nord

Sabine Reinhold

Ornements, bijoux, équipement personnel et armes présents dans les tombes peuvent être définis comme restes d'anciens assemblages de costumes et d'armes, liés à l'identité sociale de la personne ensevelie. Sur des sites de la fin de l'âge du bronze et du début de l'âge du fer en Caucase du nord, de nombreuses tombes richement équipées permettent la reconstruction de groupes de costumes et d'armes distincts, qui peuvent être rattachés à des facteurs structurant ces communautés et aboutissant à une société des classes. Cet article se base sur l'étude de deux cimetières en Tchétchénie (Caucase du nord-est), qui démontre le changement dans la différentiation sociale pendant l'âge du fer avancé. En plus, on analyse de façon générale la notion de costume et les possibilités de définir, à partir du costume, des identités sociales.

Mot-clés: âge du bronze tardif, âge du fer ancien, archéologie du Caucase du Nord, costume, identités sociales

Traditionen im Wandel: Gedanken zu spätbronze- und früheisenzeitlichen Totentrachten aus dem Nordkaukasus

Sabine Reinhold

Die Forschung zur späten Bronze- und frühen Eisenzeit im Nordkaukasus entbehrt bislang weitgehend einer Diskussion der sozialen Strukturierung der dortigen Kulturen (Koban Kultur und ihre Varianten). Dieser Artikel ist ein Versuch soziale Identitäten mit Hilfe von Befunden aus Gräbern zu rekonstruieren. Die Analyse von Trachten und Bewaffnungskombinationen wird zunächst unter eher theoretischen Aspekten diskutiert, um einen terminologischen Rahmen für die Untersuchung der prähistorischen Befunde zu gewinnen. Anhand ethnologischer Analogien werden Identitätsebenen bestimmt, die die Zusammensetzung von Trachten bestimmen. Als zentrale Kriterien sozialer Differenzierung kristallisieren sich dabei horizontale Faktoren wie ethnische Zugehörigkeit, Alter, Geschlecht und Lebensstand (verheiratet/unverheiratet etc.) und vertikale Kriterien wie Reichtum oder Prestige heraus. Ein weiteres Ergebnis ist, daß sich mit einem Wandel in den sozialen Parametern, die die Zusammensetzung von Trachten bestimmen, 
auch deren Aussehen ändert. Trachten könne in Verbindung mit anderen Kriterien als Indikatoren für soziale Veränderungen innerhalb einer Gemeinschaft gelten.

Am Beispiel von verschiedenen Fundregionen im Nordkaukasus mit reichen Grabtrachten werden solche Strukturen im archäologischen Material untersucht. Das Ergebnis ist eine sehr statische Gliederung der Beigaben in hierarchischen Klassen, die auf eine horizontale Abstufungen innerhalb der dortigen Gesellschaften während der späten Bronze- und frühen Eisenzeit deuten. In einem fortgeschrittenen Stadium der Eisenzeit lösen sich die starren Strukturen zugunsten individuelleren, weniger statischen Trachten auf. Zudem fächern sich diese Trachten sehr deutlich in arme und reiche Inventare auf. Insgesamt läßt sich eine deutliche Veränderung in der Gesellschaftsstruktur der nordkaukasischen Gruppen in der Spätbronze- und Eisenzeit postulieren. Allerdings scheint die soziale Auffächerung im Nordkaukasus weniger differenziert zu sein, als dies etwa in den mitteleuropäischen Hallstatt und La Téne Zeit der Fall ist.

Schlüsselbegriffe: Bronzezeit, Eisenzeit, Nordkaukasische Archäologie, Soziale Identitäten, Tracht

Традиции и иновации: к вопросу о погребаъных костюмах на Северного Кавказа в эпоху поздней бронзы - раннего железа

Sabine Reinhold

Исследование посвящено изучению социальной структуры Кобанской культуры и ее варианпов в зпоху поздней бронзы и раннего железного века. Статья явАяется новой попыткой реконструкции социальных групп на основе погребального инвентаря. Работу предваряет теоретическое обоснование терминологических рамок для исследования археологических находок. На основе зтнологических аналогий были опредемены уровни сочетания признаков костюма и комплекса вооружения. Как основные критерии социальных различий выкристализовываются горизонтальные факторы - этническая принадлежность, возраст, пол и социальное положение (семейный/неженатый и т.д.) и вертикальные - богатство и престижность. САедующим наблюдением является то, что с изменением социального статуса, который опредемяет сочетание костюма и инвентаря, изменяется также внешний вид состав яющих это сочетание. Таким образом, опредеменный костюм и инвентарь в сочетании с другими критериями служат индикаторами социальных изменений внутри одного и того же общества.

К анализу привлечены материалы из различных памятников Северного Кавказа с остатками богатых костюмов. Результатом является констатация очень стабильного набора инвентаря и костюма внутри иерархических групп, которое выявляет четкую горизонтальную стратификацию общества в период поздней бронзы и раннего железа. На последующей стадии железного века исчезает четкая стратификация. Сочетания костюма и инвентаря становятся более индивидуальными. В целом устанавливается опредеменное изменеие в общественной структуре северокавказских групп в эпоху поздней бронзы и в раннем жемезном веке. В то же время социальная дифференцация северокавказского общества менее выражена по сравнению с обществами Средней Европе в эпоху гальштатской и матенской кумьтур.

Ќейворас: Кобанская культура, Костюм, Социалъний тождество, Бронзый и раннего железный век 